Program Requirements to Advance the Technology of Custom Footwear Manufacturing
Howard T. Moncarz

U.S. DEPARTMENT OF COMMERCE

Technology Administration

National Institute of Standards and Technology

Manufacturing Systerns Integration Division Gaithersburg, MD 20899

QC

100

NIT

.456

NO. 5521

1994 

Program Requirements to Advance the Technology of Custom Footwear Manufacturing
Howard T. Moncarz

U.S. DEPARTMENT OF COMMERCE

Technology Administration

National Institute of Standards

and Technology

Manufacturing Systems Integration Division

Gaithersburg, MD 20899

October 1994

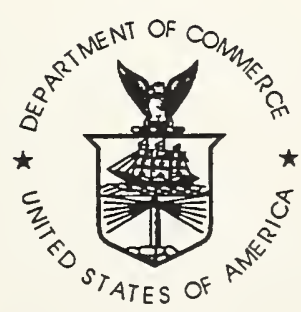

U.S. DEPARTMENT OF COMMERCE

Ronald H. Brown, Secretary

TECHNOLOGY ADMINISTRATION

Mary L. Good, Under Secretary for Technology

NATIONAL INSTITUTE OF STANDARDS

AND TECHNOLOGY

Arati Prabhakar, Director 



\section{DISCLAIMER}

No approval or endorsement of any commercial product by the National Institute of Standards and Technology is intended or implied. Certain commercial equipment, instruments, or materials are identified in this report in order to facilitate understanding. Such identification does not imply recommendation or endorsement by the National Institute of Standards and Technology, nor does it imply that the materials or equipment identified are necessarily the best available for the purpose.

This publication was prepared by United States Government employees as part of their official duties and is, therefore, a work of the U.S. Government and not subject to copyright. 



\title{
PROGRAM REQUIREMENTS to ADVANCE the TECHNOLOGY of CUSTOM FOOTWEAR MANUFACTURING
}

\author{
Howard T. Moncarz \\ Manufacturing Engineering Laboratory \\ National Institute of Standards and Technology \\ Gaithersburg, Maryland
}

\begin{abstract}
The National Institute of Standards and Technology (NIST) and the South Carolina Research Authority (SCRA) co-hosted the first Custom Footwear Manufacturing Workshop in Charleston, SC on March 10-11, 1994. At the workshop we discussed the potential creation of a nationwide, collaborative research and development (R \& D) effort to benefit the American footwear industry. The group of participants was comprised of top-level executives and leading technologists from diverse organizations-custom footwear manufacturers and footwear industry suppliers; trade associations for therapeutic footwear and for mainstream ready-to-wear footwear; professional societies representing foot and ankle health professionals; apparel and textile R \& D organizations, the Army, the Air Force, and others.

During the workshop we discussed applicable technologies for custom and therapeutic footwear manufacturing, related business requirements, national impacts on the economy and health care, and potential strategies to launch a nationwide $\mathrm{R} \& \mathrm{D}$ effort. We decided that our best strategy will be to concentrate initial efforts on the technology requirements of therapeutic footwear. We believe that the proper development, commercialization, and particularly, the integration of the advanced technologies discussed will enable the cost-effective design, manufacture, and distribution of therapeutic footwear. The resulting cost benefit to national health care, because of the major cost avoidance of much more expensive medical treatment, will be enormous.
\end{abstract}

At the workshop's conclusion we agreed on action items to continue the effort begun. This report documents the workshop and is intended as a starting point to initiate the $R$ \& D program proposed.

\section{KEYWORDS}

custom footwear, footwear manufacturing, pedorthic footwear, pedorthist, therapeutic footwear 


\section{ACKNOWLEDGMENTS}

I would like to thank the participants of the March 10, 1994 Workshop for Custom Footwear Manufacturing (as well as others who could not attend the workshop) who provided me with the information that I compiled for this report. I tried to represent the information presented at the workshop by each presenter as accurately as possible, within the limits of the notes I took during the workshop, plus some follow-up afterwards. However, another important priority was expediting the publication of this report so that it could help launch a nationwide $\mathrm{R} \& \mathrm{D}$ program to advance the technology for custom footwear manufacturing.

Additionally, I would like to thank Jeane Ford, the Manager of the Apparel Technology Program at the National Institute of Standards and Technology, who was instrumental in enabling this effort to go forward. Ultimately, this effort will enable Americans to obtain affordable, attractive, and custom-fit shoes. As was pointed out at the workshop, the original ideas to accomplish that feat have been around for over twenty years. Ron Martell, CEO of Microdynamics Corporation, said at the workshop, "nothing can stop an idea whose time has come." The workshop participants believe that the time for affordable, attractive, custom footwear is now. 


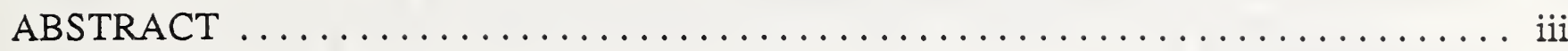

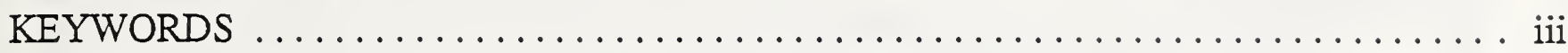

ACKNOWLEDGMENTS .............................. iv

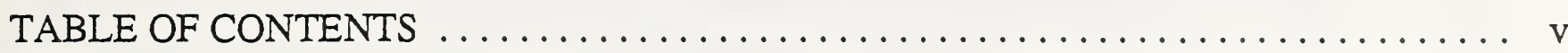

$1 \quad$ INTRODUCTION $\ldots \ldots \ldots \ldots \ldots \ldots \ldots \ldots \ldots \ldots \ldots \ldots \ldots \ldots \ldots \ldots$

2 A COLLABORATIVE R \& D PROGRAM ...................... 3

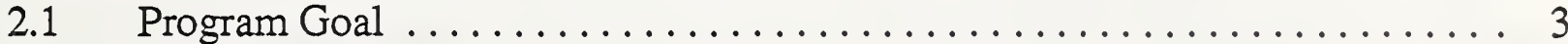

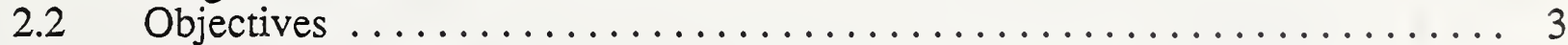

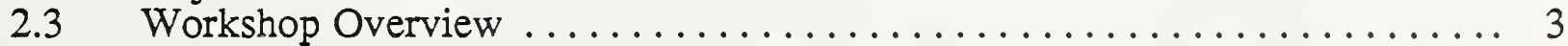

3 TECHNOLOGIES FOR CUSTOM FOOTWEAR MANUFACTURING . . . . . . . 6

3.1 Custom Shoe Manufacturing $\ldots \ldots \ldots \ldots \ldots \ldots \ldots \ldots \ldots \ldots \ldots \ldots \ldots \ldots \ldots$

3.2 Medical Considerations .......................... 7

3.3 Rapid Prototyping Techniques and Considerations $\ldots \ldots \ldots \ldots \ldots \ldots . . . \ldots$

3.4 Previous National Efforts for Footwear $\mathrm{R} \& \mathrm{D} \ldots \ldots \ldots \ldots \ldots \ldots \ldots \ldots$

3.5 The Human/Footwear Interface . . . . . . . . . . . . . . . . . . . . . . . . . 10

3.6 The Army's Interest In Improved Footwear . . . . . . . . . . . . . . . 12

3.7 A Custom Footwear Business Model . . . . . . . . . . . . . . . . . . . . . . 12

3.8 Information Requirements . . . . . . . . . . . . . . . . . . . . . 15

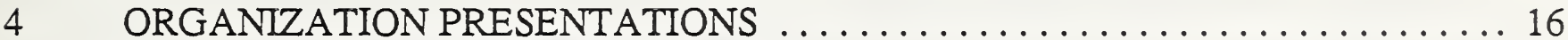

4.1 South Carolina Research Authority ....................... 16

4.2 National Institute of Standards and Technology ................. 17

4.3 Textile/Clothing Technology Corporation ....................... 19

4.4 The AMTEX Partnership TM............................ 19

4.5 University of Massachusetts Dartmouth .................... 23

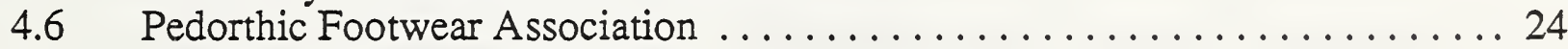

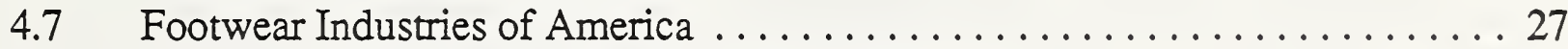

4.8 Shoe and Allied Trades Research Association .................. 27

5 PANEL DISCUSSION OF INDUSTRY TECHNOLOGY NEEDS . . . . . . . . . . . 29

6 STRATEGY TO LAUNCH A COLLABORATIVE R \& D PROGRAM . . . . . . . 32

6.1 Where Do We Go from Here? . . . . . . . . . . . . . . . . . . 32

6.2 Resources Available from the Workshop Participants . . . . . . . . . . . 33

6.3 Identifying Funding Sources $\ldots \ldots \ldots \ldots \ldots \ldots \ldots \ldots \ldots \ldots \ldots \ldots \ldots \ldots \ldots$

6.4 Conclusions and Action Items $\ldots \ldots \ldots \ldots \ldots \ldots \ldots \ldots \ldots \ldots \ldots \ldots \ldots \ldots \ldots$ 


\section{APPENDICES}

A WORKSHOP ATTENDEES' MAILING LIST

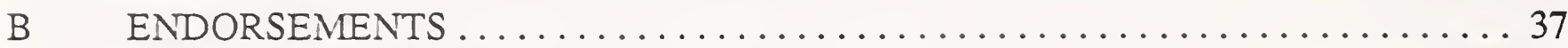

B.1 Therapeutic Footwear Manufacturer ........................ 37

B.2 American Orthopaedic Foot and Ankle Society ................. 38

B.3 Pedorthic Footwear Association .......................... 39

B.4 American Podiatric Medical Association ...................... 39

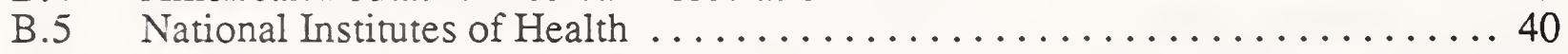

C OVERVIEW OF NIST APPAREL PROGRAM $\ldots \ldots \ldots \ldots \ldots \ldots \ldots \ldots \ldots . \ldots . \ldots$

C.1 Background ................................... 41

C.2 The APDES Project ............................. 41

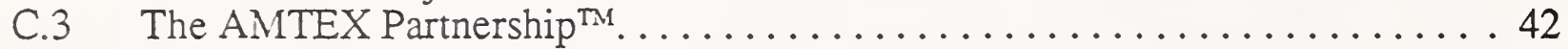

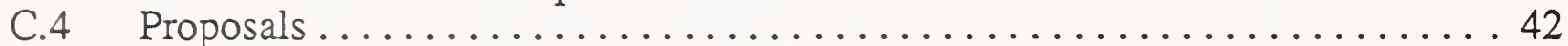

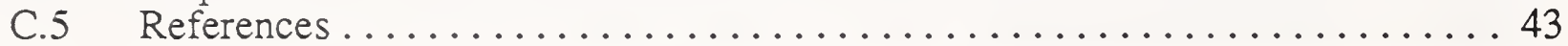

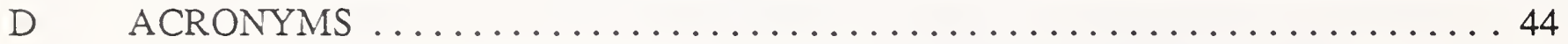

E ORGANIZATIONS RELEVANT TO THE FOOTWEAR INDUSTRY ........ 45

\section{TABLES}

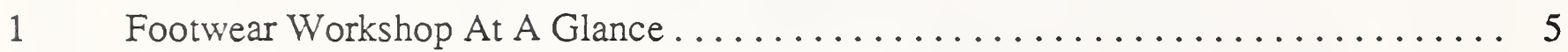

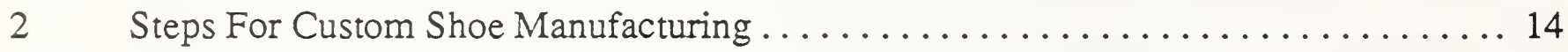

3 Quick Overview of the National Institute of Standards and Technology ......... 18

\section{FIGURES}

1 Apparel and Footwear Market Penetration $\ldots \ldots \ldots \ldots \ldots \ldots \ldots \ldots \ldots \ldots \ldots$

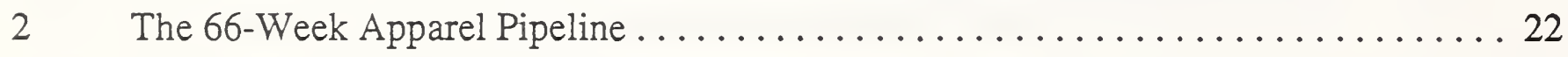

3 Percent Americans that could Benefit from Various Types of Footwear ......... 25

4 How a Consumer Has Foot Problems Resolved .................... 26 


\title{
PROGRAM REQUIREMENTS to ADVANCE the TECHNOLOGY of CUSTOM FOOTWEAR MANUFACTURING
}

\author{
Howard T. Moncarz \\ Manufacturing Engineering Laboratory \\ National Institute of Standards and Technology \\ Gaithersburg, Maryland
}

The U.S. domestic shoe ${ }^{1}$ market is $\$ 32$ billion a year at retail, which translates to over 1.5 billion pairs of shoes sold annually. Just 25 years ago, $80 \%$ of the shoes bought in this country were manufactured here. Now, however, that $80 \%$ figure has shrunk to only $12 \%$, with the number of domestic shoe manufacturers likewise reduced.

A very small part of the market, about $0.01 \%$, includes custom-manufactured shoes, where the shoe is manufactured to a specific individual's fit and, perhaps, other needs. In the custom shoe market less than 100,000 pairs of shoes are sold a year; those shoes are sold principally for health reasons. The low volume sold is due to the high labor content required, and results in a prohibitively high cost to the consumer. That cost is about $\$ 500$ a pair-just for proper fit, either for normal or for therapeutic shoes. For a custom shoe that is also aesthetically pleasing, the cost is typically from $\$ 700$ to $\$ 1000$ a pair.

Although, the custom-footwear segment is small, the potential cost benefit to the country's health care system is huge. As one example (as discussed in Section 3.2 below), over 54,000 diabetics lose a foot or a leg each year to their disease, at a medical cost of $\$ 35,000$ to $\$ 40,000$ each for the operation (and not including the many additional costs to them and society). It has been estimated that $80 \%$ of those amputations could have been prevented by the use of proper, therapeutic footwear-a total medical-cost savings estimated at about $\$ 1.5$ billion per year.

Until recently, the U.S. government did not pay for footwear as a preventive measure (unlike many other countries), instead paying tens of thousands of dollars later for foot surgery. Recently, government policy has changed, and Medicare will now help pay for therapeutic shoes for diabetics. Consequently, more people who require custom shoes for health reasons will be able to afford them.

To enable business to fully exploit the technology and expand the custom shoe market, two accomplishments are required. First, technology must lower the cost for the entire process, from the foot measurement to the final shoe manufacture and distribution. Second, the activities involved in the entire process must be separable and interoperable, so that they can be distributed functionally and geographically. Business issues should determine where the activities should take place, not artificial limits of technology. It might make the best business sense to locate foot scanners at retail shoe stores and send the foot measurements electronically to the manufacturers. Furthermore, separating the functions can enable the footwear-supplier companies to compete more effectively on the development of the separate technologies involved. The competition will serve to lower the cost and, additionally, improve the quality of the technologies developed.

\footnotetext{
${ }^{1}$ In this report, the terms shoe and footwear are used interchangeably.
} 
Whether and to what extent people will buy custom shoes for non-health reasons will ultimately depend on the cost of custom shoes relative to ready-to-wear shoes. The current U.S. custom shoe industry is too small and fragmented to create the research and development program necessary to complete the technologies required and to integrate them. However, the industry has expressed interest to develop an industry consortium, and with government support, to collaboratively develop the appropriate research and development program needed.

To explore launching an $\mathrm{R} \& \mathrm{D}$ program to address the issues discussed above, a workshop was convened on March $10-11,1994$. This report documents that workshop. 


\subsection{Program Goal}

The ultimate goal of the proposed $\mathrm{R} \& \mathrm{D}$ program is to establish an infrastructure to provide information and technology assistance to benefit the American Footwear Industry. ${ }^{2}$ The infrastructure will help advance the state of design, production, and distribution of world-class, reasonably-priced footwear in quick response to consumer demands.

A major component of the program will be an information infrastructure that will connect manufacturers, retailers, industry suppliers, information resources, and even consumers. In addition, the program will be designed to produce separable and interoperable technology components that can be connected to the infrastructure in a standardized way. The "toolbox" of components will be available for a business to determine how to configure and use them to its own best economic advantage.

The program to develop the infrastructure for the entire footwear industry can be initiated with a smaller, more manageable effort. The initial program will focus on the manufacture of custom shoes, in particular, custom, therapeutic shoes. Because of the nation's strong resolve to improve its industrial base, in addition to the nation's current priority to improve its health-care system, the therapeutic footwear segment of the industry may have the best opportunity for funding. Furthermore, the needs of the therapeutic footwear segment are very imminent and provide the opportunity to ensure that small businesses within the footwear industry will not be neglected in the long term program.

\section{$2.2 \quad$ Objectives}

The long-term program goal will address the technology needs of the entire industry. Specific long-term objectives of the $\mathrm{R} \& \mathrm{D}$ program may include:

- determine the technology needs for successful domestic and global competitiveness;

- leverage nationwide $R \& D$ to solve technology problems which have the greatest potential pay backs and reduce redundant $\mathrm{R} \& \mathrm{D}$;

- establish an information infrastructure to enable American footwear manufacturing companies to use information to their advantage; and

- improve the information flow among footwear manufacturers, suppliers, retailers, and consumers to reduce revenues lost from distressed prices, inventory cost, and stock-outs (i.e., bring the consumer closer to the manufacturer).

However, the main focus of the March 10-11 workshop was to discuss the requirements for custom footwear manufacturing, particularly for therapeutic purposes, as described in the next section.

\subsection{Workshop Overview}

The workshop was held at the South Carolina Research Authority (SCRA) in Charleston, South Carolina. The purpose of the workshop was to discuss the creation of a nationwide, collaborative research and development program on behalf of the American footwear and related industries. Although the long-term program is intended to benefit the entire footwear industry, it was

\footnotetext{
${ }^{2}$ In this report, the American Footwear Industry includes the footwear and allied industries.
} 
decided at the workshop that we concentrate our efforts to address the technology requirements of custom footwear, particularly custom, therapeutic footwear.

The proper development, commercialization, and particularly integration of the technologies discussed will enable the establishment of a nationwide system for the cost-effective design, production, and distribution of therapeutic footwear. The system will benefit people who need therapeutic shoes and will also benefit those who would want better fitting shoes if they were available at lower prices. The impact will be an improvement in the foot health of many people and will ultimately result in lowering the cost of foot treatment later on. Proper fit through custom footwear is a great preventive measure to lower the cost of foot treatment. ${ }^{3}$

During the workshop we discussed the technology requirements and relevant business needs for a successful, custom-footwear industry, determined the level of interest and commitment from the participants, and discussed the steps to continue the effort.

The agenda of the workshop is shown in Table 1.

${ }^{3}$ In a news release dated June 17, 1994, Glenn Pfeffer, M.D. and Chairman of the American Orthopaedic Foot and Ankle Society Committee on Orthoses-Footwear, noted that the estimated cost of surgery for common foot problems for women as a result of wearing poorly fitting shoes is about $\$ 3.5$ billion annually. Additionally, the surgery results in 15 million lost work days annually. 


\section{Introduction}

Robert Henderson, SCRA Welcome

\& Howard Moncarz, NIST

$\begin{array}{ll}\text { Howard Moncarz } & \text { Workshop overview } \\ \text { Doug Ferguson } & \text { Participant introductions }\end{array}$

Technologies for Custom Footwear Manufacturing

\begin{tabular}{|l|l|}
\hline Arnie Davis & Davis Shoe Therapeutics; Custom Shoe Manufacturing \\
\hline William Davis & American Orthopaedic Foot \& Ankle Society; Medical \\
\hline Considerations & Stevens Institute; Rapid Prototyping Techniques \& \\
\hline Lee McKinley & Considerations \\
\hline Kathleen Robinette & Air Force; The Human/Footwear Interface \\
\hline Steve Paquette & Army Natick; The Army's Interest in Improved Footwear \\
\hline Ron Martell & Microdynamics; A Custom Footwear Business Model \\
\hline Robert Wallace & Electronic Softgood Products; Information Reguirements \\
\hline Organization Presentations & South Carolina Research Authority (SCRA) \\
\hline Doug Ferguson & Nextile/Clothing Technology Corporation ([TC] ${ }^{2}$ ) \\
\hline Howard Moncarz & American Textile Consortium (AMTEX) \\
\hline Judson Early & University of Massachusetts Dartmouth, Mass. Shoe Industry \\
\hline Richard Quisenberry & Pedorthic Footwear Association (PFA) \\
\hline Ron McNeil & Footwear Industries of America (FIA) \\
\hline Bill Boettge & Shoe and Allied Trades Research Association (SATRA) \\
\hline Fawn Evenson & \\
\hline Fawn Evenson & \\
\hline Panel Discussion of Industry Technology Needs \\
\hline Panelists: Greg Alaimo (Acor Orthopaedic, Inc.), Arnie Davis, \& Lee McKinley \\
\hline Strategy to Launch Collaborative R \& D Program \\
\hline Where Do We Go from Here? \\
\hline Resources Available from the Workshop Participants \\
\hline Identifying Funding Sources \\
\hline Conclusions and Action Items \\
\hline
\end{tabular}

Table 1 Footwear Workshop At A Glance 
To zero in on the technology needs to enable cost-effective custom shoe manufacturing, the relevant technologies must first be specified-including the technologies that are already available, those that are required, and those that would be desired. The workshop began with a broad-brush overview of the relevant technologies, as well as brief assertions of the technology needs.

\title{
3.1 Custom Shoe Manufacturing
}

\author{
Arnie Davis \\ President and Board Certified Pedorthist ${ }^{4}$ \\ Davis Shoe Therapeutics \\ San Francisco, CA
}

Arnie Davis started his professional career as a sculptor but decided to return to school to learn the art of therapeutic footwear manufacturing. His diverse background in art, manufacturing, and business gives him unique qualifications to understand the needs of therapeutic footwear designers and manufacturers.

Custom shoes are made for three main reasons:

- fashion or costuming,

- therapeutic, or

- combination of fashion and therapeutic.

In general, therapeutic shoes look boxy and ugly-they look like the feet. The fashion shoe that is also therapeutic is the rarest type of custom shoe and is very expensive to make.

Custom footwear must be designed to accommodate:

- fit and

- function-how to distribute forces for alignment and balance.

The key to creating a custom shoe is the "last." The last is the mold over which the shoe is made, and its shape influences how the shoe will be made. The shoe cannot be simply made over the mold of the foot if the shoe is to fit and perform properly, because:

- extra space is needed in the front for normal movement of the toes within the shoe;

- fit is required to the bones, not the skin, in the back sides of the shoe to hold the shoe on; and

- a slope is needed under the front of the shoe, called the "toe spring," that enables the shoe to roll in a natural way while walking.

In addition to fit and function, the style of the shoe is captured in the shape of the last.

There are two general approaches to make a last for a custom shoe:

- start with the shoe shape and modify it to account for fit and other corrections or

- start with a molded last of the foot shape and modify that to obtain the shoe shape, adding the proper corrections.

\footnotetext{
${ }^{4}$ Dorland's Medical Dictionary defines pedorthics as:

"The art concerned with the design, manufacture, fit, and modification of shoes and related foot appliances as prescribed for the amelioration of painful or disabling conditions of the foot and limb."

Pedorthics, published by the Pedorthic Footwear Association, states:

"Pedorthic therapy is intended to relieve and aid in the care of injury, deformity or disease. The certified pedorthist provides medically related specialty footwear services that affect the ability of people to function. ... The physician provides the prescription from which the certified pedorthist designs and fits the prescribed therapeutic footwear for the patient."
} 
The first approach, modifying the shoe shape, is generally done for a fit problem. The second approach, starting from the foot shape, is generally used to make therapeutic shoes.

Providing proper corrective footwear is an iterative process. After fitting the shoe, the pedorthist must look for pressure points. For example, if the heel of the shoe is raised approximately 35 millimeters $\left(1^{1 / 2}\right.$ inches) above the sole, the normal pressure can be increased over 60 to $70 \%$ at certain points on the foot. Some pressure is acceptable for some patients if it is not excessive. However, for diabetic patients the pressure on the foot needs to be distributed equally to avoid problems. A way to determine high pressure areas on the foot early in the shoe design process would be very beneficial.

Custom shoe makers serve an important purpose to a not-insignificant segment of the population. Unfortunately, custom shoe makers are dying out; their craft, which is still an art, is dying with them. In the European Union (or EU, formerly the European Community or EC; and previous to that, the Common Market), there is an eight-year program to obtain a Masters Degree in custom footwear manufacturing. However, to become a really good shoe maker, it takes about twenty years to learn the craft. That still doesn't guarantee that the shoe maker will develop the artistic talent sufficient, given the current state of the craft, to make a good-looking shoe for a particular person's foot needs. 5

One important industry need that will help the custom shoe maker is an improved method of getting a mold of the foot to the shoemaker. A second important assistance to this industry segment is the recent bill that passed Congress that provides Medicare support to diabetics who need therapeutic footwear. The bill mandates that government will pay up to $80 \%$ of the cost of therapeutic footwear. The maximum stipend allowable from the government is $80 \%$ of $\$ 348.00$ or $\$ 278.40$.

\subsection{Medical Considerations}

Dr. William Hodges Davis

Orthopaedic Surgeon

Representative of the American Orthopaedic Foot and Ankle Society

Dr. William Davis is an orthopaedic surgeon with fellowship training in the subspecialty area of foot and ankle surgery. His practice is composed of $90 \%$ of foot and ankle patients. Presently, the clinic where he practices, the Foot and Ankle Center of the Miller Orthopaedic Clinic, has 300 to 350 diabetic patients under active care.

Therapeutic footwear can provide dramatic health improvement to a number of patient populations, and, furthermore can greatly reduce nationwide health care costs. A sizable population that can benefit is the diabetic-patient population. Diabetics often have insensitivity in their feet. They can wear very poorly-fitting shoes, and they don't know it because their feet don't hurt. Eventually, their shoes can cause them deformities which greatly increase the

${ }^{5}$ Bill Boettge pointed out that the approach taken by the EU to provide therapeutic shoes has been different than the U.S. The EU has attempted to provide custom footwear for everyone who needs it. However, that is too expensive a proposition, and the EU is now looking at and is very interested in the methods used in the U.S. to modify off-theshelf "orthopedic" shoes (e.g., extra-depth shoes). 
likelihood of developing foot ulcers, which can often lead to foot amputation. Diabetics, in general, have a fine blood supply; their main problem is foot insensitivity. ${ }^{6}$

"Today, more than 13 million people in the United States have diabetes. Unfortunately, more than half are not aware that they have the disease. . . . Diabetes is the most frequent cause of non-traumatic lower limb amputations. The risk of a leg amputation is 27.7 times greater for a person with diabetes. Each year, 54,000 people lose their foot or leg to diabetes."7 According to a letter from Dr. Davis, "It has been determined that $80 \%$ of these amputations that are done per year are preventable. That would be approximately 45,000 amputations that are preventable each year. It is our estimate that not only are these devastating problems in that patients most often don't walk afterwards, but they never will be participators in the financial systems again."

The medical costs alone of those amputations (not including other costs resulting to the individual and the country from the disability) is on the order of $\$ 35,000$ to $\$ 40,000$ per patient. ( 45,000 times $\$ 40,000$ equals $\$ 1.8$ billion of potential cost savings.) Before the Medicare support, government would spare no expense to pay for an operation, but would not contribute any funding for footwear that could be preventive.

A second patient population requiring therapeutic footwear are the arthritic patients. Patients with rheumatoid arthritis can get terrible deformities in their feet to the point that they can't fit into any shoes. The progression of rheumatoid arthritis to deformity is inevitable; the only question is the speed of that progression. Therapeutic footwear can slow that progression, and lengthen the time before those patients are disabled.

A third patient population that will benefit from therapeutic footwear are those who have suffered a trauma injury to their feet and/or have had reconstructive foot surgery. In some cases, those patients can do fine with specially designed shoes, but are unable to wear ready-to-wear shoes at all.

Prohibitive cost for custom footwear is only part of the problem. People want shoes that look good. If patients won't wear therapeutic footwear, reducing the cost of that footwear is irrelevant. The attractiveness of therapeutic footwear must be improved. A third problem concerns distribution of the therapeutic footwear. Linking the patient who needs special footwear to the proper medical professional and to the special footwear provider, such as the pedorthist, can be difficult. For example, there are a limited number of pedorthists in the country and they are largely concentrated in the urban areas.

A pedorthist is necessary to provide the link between the prescription from a doctor and the patient's fit needs-to provide the corrections necessary. The Foot and Ankle Society is closely aligned with the Pedorthic Society. A good pedorthist is essential to, literally, save a person's leg; we need to keep them in business.

On the order of 10,000,000 people in the U.S. could benefit from therapeutic footwear. Most of those are not using that type of footwear. The reality is that we need therapeutic footwear that can be provided at a reasonable price and, additionally, in an aesthetically-pleasing look.

\footnotetext{
${ }^{6}$ These conclusions are supported by a study conducted at a major Veterans Administration medical center and reported at a recent American Orthopaedic Foot \& Ankle Society meeting (as cited in the Pedoscope, April/May 1994).

7 Source: "Diabetes Facts," American Diabetes Association, September 1993.
} 


\title{
3.3 Rapid Prototyping Techniques and Considerations
}

Dr. Costas Chassapis 8

Professor of Mechanical Engineering

Stevens Institute of Technology

Hoboken, NJ

Professor Costas Chassapis is an expert in Rapid Prototyping techniques.

Rapid Prototyping (RP) is a term given to the very rapid production of one-of-a-kind parts directly from computer generated models of the parts. RP does not require the typical steps used in traditional machined prototype methods, such as generating the numerical control (NC) toolpath for a machine tool. A number of different technologies have been developed to do RP. Each technology has its own associated costs, process times to actually produce the prototype, materials it can use, and the types of prototype geometries and sizes it can accommodate. The cost of RP for making lasts is prohibitive at present for using RP in custom footwear manufacturing; however, developments currently underway indicate that the costs are coming down, and eventually could be low enough for that type of application. ${ }^{9}$

\subsection{Previous National Efforts for Footwear R \& D}

\author{
Lee McKinley \\ Footwear Industry Consultant \\ Chapel Hill, NC
}

\begin{abstract}
Lee McKinley worked for over thirty years as head of shoe manufacturing for a number of companies. In his last ten years in that capacity he was in charge of manufacturing operations for Florsheim Shoe Company. In 1981, Mr. McKinley left Florsheim to head the technology program of the American Show Center (now the Footwear Industries of America, or FIA). He served in that capacity until 1993. Since then, Mr. McKinley has been an independent consultant to the footwear industry.
\end{abstract}

In the early 1970s American footwear manufacturers produced $640,000,000$ pairs of shoes per year. Today that figure is down to approximately $170,000,000$ pairs, due primarily to the penetration of imports from low labor cost countries in the Far East. The Florsheim Shoe Company is typical of many domestic footwear manufacturers. During the 1970s Florsheim had 23 domestic manufacturing and supply plants, producing over 20,000 pairs of men's and women's shoes daily. Today, primarily due to cheap foreign labor, most of the Florsheim plants have been closed and the bulk of the shoes are now sourced overseas. Florsheim has only 3 domestic plants remaining.

In the early 1980s the Department of Commerce established an R \& D center to strengthen the technology base of the beleaguered U.S. footwear industry. To kick off the effort, the Department of Commerce funded a study to determine the world-wide state of the art for footwear technology, and to establish mechanisms and priorities for the advancement of new

${ }^{8}$ Costas Chassapis and his colleague Fred Swern, also from Stevens Institute, became interested in custom shoe manufacturing due to the efforts of Phil Massaro from the Industrial Technology Assistance Corporation (ITAC). (The mission of ITAC is basically to help New York State small businesses stay in business.)

${ }^{9}$ Note: a recent publication by Kevin Jurrens from NIST may be of interest. Refer to Jurrens, K. K., An Assessment of the State-of-the-Art in Rapid Prototyping Systems for Mechanical Parts, NISTIR 5335, National Institute of Standards and Technology, Gaithersburg, MD, December 1993. 
technology in the industry. FIA's English partner, the Shoe and Allied Trades Research Association (SATRA), in cooperation with shoe companies throughout the United States, Europe, Canada, and the Far East, participated in the study. ${ }^{10}$ The study formed the basis for FIA's technology program, and included the following efforts:

- initiation of materials and whole shoe testing through FIA's SATRA-directed testing laboratory;

(This included establishing and publishing, for the first time, a compendium of footwear test methods that is now universally accepted by the industry.)

- establishment of a footwear Materials and Products Committee;

- implementation of a footwear CAD/CAM training center;

- introduction of "SHOE TECH"- a machinery, materials, and systems conference and exhibition, including plenary sessions for footwear technology;

- formation of technology task forces and committees, comprised of the industry's leading manufacturing and supplier companies;

- establishment of a Robotics Task Force;

- establishment of a New Technology Task Force;

- introduction of the Universal Product Code (UPC) for bar coding footwear;

- establishment of a stitcher instructor training course;

- establishment of an interactive video-based supervisory skills training program;

- establishment of technology conferences and seminars;

- initiation of a shoe factory audit program to evaluate shoe machinery and systems technology; and the

- development of a proposal to establish a Department of Defense (DOD) / Defense Logistics Agency (DLA) "Instrumented Shoe Factory."

This last program effort, the "Instrumented Shoe Factory," was initiated by DOD in 1990. The intent was to establish a footwear manufacturing demonstration center and beta test site for footwear manufacturing, similar to the DLA apparel manufacturing demonstration centers. Equipped with state-of-the-art technology, the proposed center was to have the University of Virginia (UVA) as its partner. UVA promised to donate the manufacturing site (to be located on campus in Charlottesville, VA) and to provide university support from students and faculty from the Mechanical and Aerospace Engineering Department. In addition, manufacturers and suppliers throughout the industry gave commitments of personnel and equipment for the proposed site, and DOD promised six million dollars for the project. After two years of planning, the program was abruptly canceled after DOD withdrew its support, due to Congressional budget cuts.

\subsection{The Human/Footwear Interface}

Ms. Kathleen Robinette

Research Physical Anthropologist

Armstrong Laboratory, Crew Systems Directorate

Wright Patterson Air Force Base, OH

Kathleen M. Robinette is the program manager for the Computerized Anthropometric Research and Design (CARD) Laboratory at Wright-Patterson Air Force Base. She is also the senior technical expert for exploratory development efforts for the U.S. Air Force in the broad area of anthropometry,

${ }^{10}$ The study was published in 1983 — refer to DOC Project No. 99-26-07124-10, 1983. 
and its application to the design and evaluation of personal-protective equipment and clothing. She is one of the leading international experts in engineering anthropometry with seventeen years of practical experience.

It is possible to have hundreds of body size and shape measures on hundreds of thousands of people and still not have the information to design something to fit. Large anthropometric surveys help characterize the population, but not the fit. In order to characterize the fit, the fit must be measured. In order to determine the anthropometry relevant to the fit of a particular item, the "fit" of the item must be measured along with the anthropometry. We call this measuring the interface.

It is often the case that each new design fits differently, in other words, each fits a different segment of the population even though it may have been "designed" to be the same size. For example, a $T$-shirt size medium fits a much broader range of people than a medium dress shirt. The study of the interface between human body measurements and something that is worn or operated by people (such as clothing, footwear, control positioning, etc.) is one of the main foci of the Computerized Anthropometric Research and Design (CARD) Laboratory. Toward this end, several new tools have been developed to aid in the measurement of the interface. One tool is an automated 3-D surface scanner, originally intended for artistic use. The company who makes the scanner, Cyberware, Inc. was using it for digitizing the head and face of actors for movies and people who might want to have busts made for display. CARD laboratory personnel worked with Cyberware to turn it into a measuring tool and have been collecting data with it since 1987. The current version of the system we are using collects about 130,000 points on the head and face in approximately 12 seconds.

A second tool developed is a method for bringing together or registering the scans. This tool is used to visualize and measure the geometric relationship between the person and the equipment they wear. It allows us to compare the good fit cases to the bad fit cases in a manner never before possible, by permitting an " $\mathrm{x}$-ray" view of the person in the equipment.

Other tools include advanced methods for assessing the fit itself. Traditional anthropometric technologies are generally not sufficient to measure that interface, because they are very limited in their ability to measure the equipped person. This is critical since the variation in which people wear things is much larger than the variation in people's anthropometric measurements. ${ }^{11}$

Some of the areas that CARD has been involved in that have relevance to this workshop include:

- Burn treatment program: to create a face mask for burn victims who have facial scars

- Prosthetic device research with the Veterans Administration (VA) hospital at the University of Washington: to go from the stump to a prosthetic device

- Sports mask development

- Whole body scanner: to modify a Cyberware measurement system at the Idaho national laboratory for applications such as custom apparel manufacturing

- Multifaceted demographic data system: to archive and link anthropometric and other types of data for various target populations (includes analysis and data visualization capabilities)

- NATO Anthropometric Survey: to create a database of demographic information that is not restricted to body information and is searchable by different queries

${ }^{11}$ Amie Davis commented that different people who have the same foot measurements often want different fitting shoes. 
Opportunities and challenges for R \& D in footwear manufacturing include:

- data networking and exchange (data standards are needed to communicate information among the different processes in the product life cycle so that information is not lost),

- rapid prototyping, and the

- footwear interface (as described above).

\title{
3.6 The Army's Interest in Improved Footwear
}

Steve Paquette

Anthropology Coordinator

U.S. Army Natick

Natick, MA

Army Natick may have a role to play in this effort somewhere down the line. During basic training, about 53 out of every 1000 male soldiers have foot or other lower extremity injuries. The figure is even higher for women-200 out of every 1000 female soldiers. Producing custom footwear that is properly fit for each soldier that could reduce these injury levels would have a definite value to the military.

Army Natick has an interest to:

- track the state of the art in manufacturing technology,

- focus on private industry coordination and collaboration, and

- improve the quality and reduce the cost of footwear for the soldier.

A small cost reduction for each pair of shoes can have a significant cost reduction when measured over all of the soldiers that need them.

The Army has responsibility for normal footwear for all of the military services. However, each service has its own group whose responsibility is clothing and shoes for the special requirements of that service.

\subsection{A Custom Footwear Business Model}

\author{
Ron Martell \\ CEO \\ Microdynamics Corporation ${ }^{12}$ \\ Dallas, TX
}

Ron Martell started his first company in 1971. The first contract he received was for developing a CAD system for footwear. Eventually, he sold that company to a Swiss company. In 1979, he started Microdynamics. That company is now the leading supplier in the world of CAD systems for footwear. However, the apparel market is 25 times larger than the footwear market, and Microdynamics is also a leading supplier to the apparel market. The four leading suppliers in the world of apparel software are Microdynamics, Gerber Garment Technology, Investronica (in Spain), and Lectra (in France).

About five years ago Ron Martell started looking into the business and technology aspects of custom footwear. The technologies to produce aesthetically-pleasing custom shoes at a cost that can support the development of a profitable business are now available.

\footnotetext{
${ }^{12}$ Microdynamics Corporation has just been bought by Gerber Garment Technology (September 1994).
} 
In discussing business models for custom shoes, two separate markets that call for two separate types of businesses with separate strategies must be distinguished. One business, the custom shoe business, concerns custom shoes for people with normal feet who would like improved fit. The second business, the therapeutic shoe business, concerns custom shoes that include therapeutic corrections to address medical problems.

The custom shoe business will mean a very different way of doing business for retailers. Retailers will not have to stock everything-all sizes, many styles-as they do now, reducing inventory costs. The current $10 \%$ return rate will be greatly reduced. Fitting different sized feet will be greatly improved. For ready-to-wear shoes in the U.S., the length increments between different half sizes are 4.23 millimeters ( $1 / 6$ of an inch). Custom shoes should do much better than that. Not to mention the fact that it is very common for people's left and right feet to be very different sizes.

There are a number of major companies that are now looking into the development of a custom shoe business. One company in Denmark has already entered the market. The company offers the customer a style and color selection and then manufactures a pair of shoes to the customer's fit at a price of $\$ 800$. In the model that Mr. Martell has presented, the price needs to be in the range of $\$ 200$ a pair for a long term, successful business. The model is summarized in Table 2.

The technologies required for the business model presented have been developed and are or will be shortly available commercially. The key technology enabler for a successful custom footwear business is integration of the component technologies.

In the first step of the model, the customer selects the style desired. Next, the foot is measured. A number of technologies have been developed to scan the foot to determine its measurements (as 3-D data). Arnie Davis mentioned that another possibility for measuring the foot, other than non-contact foot measurement systems, is to use a new technology developed by the $3 \mathrm{M}$ Corporation. That technology uses a sock that a customer puts on and removes. The sock is made of a material that will retain the shape of the foot when it is removed and can be mailed to wherever needed for manufacturing the shoe.)

After the foot has been measured, that data, together with the shoe style chosen, can be used to create the last measurements. Based on the last measurements, the shoe patterns can be created for the "upper" part of the shoe. (Note that the upper is divided into separate pattern pieces, and the details of how each pattern piece is shaped are based upon many years of knowledge from the footwear manufacturing craft.) The design for the bottom of the shoe is based on the last shape as well.

Last making is not an exact science. However, there have been a number of attempts to automate the machining of shoe lasts. The last measurements are used to control the last-manufacturing process; currently that process uses a lathe or a milling machine. ${ }^{13}$

Some companies can manufacture five pairs of shoes per last per day. As the U.S. shoe industry has declined, the U.S. last industry has declined even faster and further. There are only three last manufacturing companies left in the U.S. Manufacturing lasts out of wood used to take about two weeks. Now, the use of other materials and techniques can speed that up. Eventually, newer rapid prototyping techniques will be used to make custom lasts. In current practice, shoe companies are very careful in handling their lasts. A small defect on a last that will be used in

${ }^{13}$ Amie Davis mentioned that the idea of making different-sized lasts for the right and left feet is the impetus behind some of the recent interest in developing a custom shoe business. 
mass production will render that last obsolete. However, in manufacturing custom lasts, which will be used for a relatively small number of shoes and can be economically repaired, small last defects are not a concern.

\begin{tabular}{|c|c|c|c|}
\hline Activity & Technologies & $\begin{array}{l}\text { Process } \\
\text { Time } 14\end{array}$ & Comments \\
\hline select style and color & $\begin{array}{l}\text { manual or electronic } \\
\text { catalog; or samples }\end{array}$ & & $\begin{array}{l}\text { Some styles won't work with all } \\
\text { feet }\end{array}$ \\
\hline measure foot (3-D data) & $\begin{array}{l}\text { laser based (light } \\
\text { triangulation-many } \\
\text { points in few secs) }\end{array}$ & 5 mins & $\begin{array}{l}\text { if necessary, ultrasound, MRI, } \\
\text { etc. can determine underlying } \\
\text { bone structure }\end{array}$ \\
\hline determine last shape & software & $5 \mathrm{~min}$ & $\begin{array}{l}\text { 3-D model generated from foot } \\
\text { measurements and style choice }\end{array}$ \\
\hline generate patterns & software & & $\begin{array}{l}\text { referred to as "flattening the } \\
\text { last" }\end{array}$ \\
\hline $\begin{array}{l}\text { adjust patterns for particular } \\
\text { style and fit customizations }\end{array}$ & software & & \\
\hline $\begin{array}{l}\text { generate NC data to machine } \\
\text { last }\end{array}$ & software & & \\
\hline nest 2-D patterns & software & & $\begin{array}{l}\text { layout for cutting and generate } \\
\text { NC data }\end{array}$ \\
\hline machine last(s) & $\begin{array}{l}4 \text { axis lathe, } \\
\text { modified last lathes, } \\
4 \text { axis mills, or } \\
\text { 3-axis mills with } \\
\text { special tooling }\end{array}$ & 15 mins & \\
\hline cut upper \& bottom parts & knife NC cutter & 10 mins & \\
\hline sew and assemble & $\begin{array}{l}\text { specialized shoe } \\
\text { production machines }\end{array}$ & 2 hours ${ }^{15}$ & \\
\hline deliver shoes & $\begin{array}{l}\text { United Parcel } \\
\text { Service }\end{array}$ & 1 day & \\
\hline
\end{tabular}

\section{Table 2 Steps for Custom Shoe Manufacturing}

"Nothing can stop an idea whose time has come." A study of the applicable technologies required indicates that, appropriately integrated, it is viable to sell custom shoes at $\$ 200$ a pair. Market research shows that shoes sold at $\$ 200$ a pair and delivered in a week can realize $\$ 20$ million worth of sales the first year. Though $\$ 200$ a pair is the target price for a successful ongoing business, the product could be successfully introduced at a higher price.

A different business model is necessary for the therapeutic footwear market and is not described in this presentation. The model would be similar, ${ }^{16}$ but would include two or three additional steps; also, the cost ranges required would be different.

\footnotetext{
14 rough estimates by Mr. Martell (left blank if estimates were not given)

15 possible in 1 hour today

16 One difference for the therapeutic footwear model would be the manufacture and assembly of the shoe bottoms. The advent of unit bottoms has been a boon in simplifying ready-to-wear footwear manufacturing, because onesized bottom can be used for an assortment of different-sized uppers. However, that technique will be difficult to duplicate for therapeutic footwear manufacturing, where individual attention is required for each shoe bottom.
} 


\title{
3.8 Information Requirements
}

\author{
Robert Wallace \\ President \\ Electronic Softgood Products \\ Raleigh, NC
}

Robert Wallace presented the idea of a custom footwear manufacturing system to the Veterans Administration Hospital in Washington, D.C. ten years and two months ago today. In fact, the view graphs that he presented then are much the same as the view graphs he is using today.

From the perspective of health care cost avoidance, an effective, therapeutic, footwearmanufacturing system could save the country hundreds of millions of dollars. Mr. Wallace developed his ideas while working at the Research Triangle Park Center for Technology Applications in Raleigh, North Carolina. He worked there with Leo Weisbacher, whose work on custom shoe manufacturing goes back fifteen years. Those ideas, in turn, were based on previous NASA developments. In general, it takes an average of about twenty-seven years to spin off NASA developments into commercial products. That figure seems to be in the ballpark for the time it has taken to commercialize the custom shoe technologies.

Mr. Wallace remembers the words that Arnie Davis once told him, "the last comes first." The technology hurdle still remaining for custom shoe manufacturing is the ability to rapidly capture foot shape data and convert it to the last shape. A tool is needed that can function as "electronic clay," to enable the modification of the sculptured 3-D model of a last on the screen.

The scanner used to scan the foot must be quick, low cost, and accurate. It should be priced in the eight to ten thousand dollar range; it should be connectable to a PC compatible computer; and its accuracy should be in the range of $0.5 \mathrm{~mm}$. The technology to enable a scanner with these requirements should be available soon.

Beyond the separate technologies, there are still the total system issues that must be resolved. All the separate components must work together for the whole system to be worthwhile. That is the perspective that $\mathrm{Mr}$. Wallace first brought to the problem-the perspective of an industrial engineer looking at electronic commerce-from "art to part." From that perspective, custom footwear manufacturing is an excellent example with which to demonstrate the "CALS technologies" throughout the manufacturing life cycle of a product. ${ }^{17}$

${ }^{17}$ The acronym "CALS" stands for Continuous-Acquisition and Life Cycle Support. The CALS technologies includes information technologies in the area of standards for systems, product data, and electronic commerce that were developed to make the government and military procurement cycle more efficient. 


\title{
4. ORGANIZATION PRESENTATIONS
}

A number of organizations directly relevant to footwear manufacturing, as well as those with the resources to benefit the industry or those with applicable lessons for the industry, participated at the workshop. Each organization presented an overview which included its mission, its structure, and its relevance to the advancement of custom footwear manufacturing.

\subsection{South Carolina Research Authority (SCRA)}

\author{
Doug Ferguson \\ Principle Associate \\ South Carolina Research Authority \\ Charleston, SC
}

\begin{abstract}
Doug Ferguson is a ASQC Certified Quality Engineer with over twenty-five years experience in Quality and Project Management. Currently, Mr. Ferguson is a Principal Associate with the South Carolina Research Authority, having responsibility for the development and implementation of flexible computer integrated manufacturing (FCIM) technology.
\end{abstract}

The South Carolina Research Authority (SCRA) is a nonprofit organization established in 1983 to advance manufacturing technology for American industry nationwide. SCRA fosters joint projects among the private business sector and research institutions and is committed to the design, development, and implementation of techniques to provide a competitive edge to the U.S. manufacturing base.

To meet the challenge, SCRA has assembled teams of experienced manufacturing and computer science talent to work on a wide variety of systems and programs for industry. The teams are working on projects such as advanced manufacturing engineering systems, agile manufacturing systems, computer interpretable product data definition, product cost capture systems, and many other sophisticated systems to support the business of manufacturing. In all cases the teams formed by SCRA have established long term business agreements that go far beyond the typical prime contractor-subcontractor relationship.

Benefits obtained from the research, development, and integration of the advanced technology efforts are transferred and shared through the following techniques:

- Technology Awareness

SCRA produces and circulates bulletins and reports to industry, other research institutions, and academia to share information and results from the various projects.

- Technology Education

Seminars and workshops are provided for the industrial clients to describe the work accomplished and the information learned.

\section{- Technology Demonstration}

SCRA offers a demonstration, at least once a month, of the technology developed. The demonstration provides the user community an opportunity to see state-of-the-art commercial applications as well as state-of-the-art technology developments. Seeing the technology displayed firsthand helps SCRA's clients to develop an overall strategic plan to apply and utilize the technology in their own organizations. 


\title{
4.2 National Institute of Standards and Technology (NIST)
}

Jeane Ford

Manager, PDES Testbed and Apparel Technology Program

National Institute of Standards and Technology

Gaithersburg, $M D$

S. Jeane Ford is Program Manager for the National PDES Testbed and Apparel Technology Program at NIST. Her background includes over twenty years of experience in the advancement of engineering design and manufacturing systems, development and implementation of computer-based systems to support life cycle engineering and technical data management, and the transition of new technologies into production environments. Before joining the Department of Commerce, Ms. Ford held a number of positions in industry, including President of Pacific Motion Systems, Director of Advanced Manufacturing Technology for FMC Corporation Advanced Systems Division, and line management and engineering positions with Lockheed Corporation and McDonnell Douglas.

\author{
Howard T. Moncarz \\ Research Engineer \\ National Institute of Standards and Technology \\ Gaithersburg, MD
}

\begin{abstract}
Howard Moncarz has a diverse engineering background, and has worked in industry, academia, and government; the last ten years at NIST. His most recent work involves the development of product data standards for the apparel industry to help integrate the apparel manufacturing life cycle. In that capacity, he has discussed the needs of the industry with experts nationwide from the industry, $C A D$ vendors, universities, and government. He is using that input to help develop the NIST Apparel Technology (ATEC) Program to best utilize NIST resources to the benefit of the integrated textile industry.
\end{abstract}

The National Institute of Standards and Technology (NIST), of the U.S. Department of Commerce, is the nation's largest physical sciences, engineering, and measurement laboratory. Its mission is to improve the technology base of American industry through the development and transfer of technology to industry and through the development of standards. A capsule view of NIST is provided in Table 3.

NIST has both intramural and extramural programs. The extramural program is NIST's direct outreach program of funding support and recognition to industry and academia. The extramural program includes the Advanced Technology Program, the Manufacturing Extension Partnership Program, and the Malcolm Baldridge Quality Award Program.

The goal of the Advanced Technology Program (ATP) is to assist U.S. business to carry out R \& D on PRE-COMPETITIVE GENERIC technologies, which are:

- ENABLING -offer wide breadth of potential application and form an important technical basis for future product-specific applications; and

- HIGH VALUE-when applied they offer significant benefits to the economy by enhancing economic growth and raising productivity.

In terms of budget, the Advanced Technology Program is expected to be NIST's largest program by 1997. 


\section{NIST AT A GLANCE ${ }^{18}$}

The National Institute of Standards and Technology was established by Congress "to assist industry in the development of technology ... needed to improve product quality, to modernize manufacturing processes, to ensure product reliability ... and to facilitate rapid commercialization ... of products based on new scientific discoveries."

An agency of the U.S. Department of Commerce's Technology Administration, NIST's primary mission is to promote U.S. economic growth by working with industry to develop and apply technology, measurements, and standards. It carries out this mission through a portfolio of four major programs:
- a rigorously competitive Advanced Technology Program providing cost-shared grants to industry for development of highrisk technologies with significant commercial potential;

- a grassroots Manufacturing Extension Partnership helping small and medium-sized companies adopt new technologies;

- a strong laboratory effort planned and implemented in cooperation with industry and focused on measurements, standards, evaluated data, and test methods; and

- a highly visible quality outreach program associated with the Malcolm Baldridge National Quality Award.
BUDGET

$\$ 609$ million

(FY 94 estimated operating resources from all sources)

\section{STAFF}

About 3,200 scientists, engineers, technicians, and support personnel, plus some 1,200 visiting researchers each year

\section{SITES}

Gaithersburg, MD (headquarters234-hectare campus) and Boulder, CO (84-hectare campus)

\section{MAIN RESEARCH AREAS IN NIST LABORATORIES}

Electronics and electrical engineering

Manufacturing engineering

Chemical science and technology

Physics

Materials science and engineering

Building and fire research

Computer systems

Computing and applied mathematics

\section{Table 3 Quick Overview of the National Institute of Standards and Technology}

The objective of the Manufacturing Extension Partnership (MEP) Program is to help small and medium-sized manufacturers become more competitive by the adoption of new technologies. A key element of the MEP Program is the establishment of manufacturing extension centers throughout the country, linked together in a nationwide system to provide access to outreach and technical assistance programs of other federal, state, and local organizations. Currently, thirtyfive centers have been established, with the goal of reaching one hundred centers by 1997 .

The third extramural program, the Malcolm Baldridge Quality Award Program, awards companies who have infused world-class quality throughout their manufacturing operations. The prestige of the award has led many companies to enroll in the evaluation program, just to say they are working towards the program's goals, even without winning it.

The intramural program is NIST's internal laboratory program. The intramural program also provides for Cooperative Research and Development Agreements (CRADAs), which enable NIST's laboratory staff to work directly with industry and academia.

\footnotetext{
${ }^{18}$ This table was reproduced from page 2 of the Guide to NIST, U.S. Department of Commerce, Technology Administration, 1994.
} 
Ms. Ford and Mr. Moncarz are members of the Factory Automation Systems Division (FASD) within the Manufacturing Engineering Laboratory (MEL). The mission of FASD is to employ information technology to advance American industry.

FASD has been working with the apparel industry over the last five years to develop product data standards that can be utilized to integrate the processes in the apparel manufacturing life cycle. Many of the technologies employed in both the apparel and footwear industries have similarities and likely can be leveraged to the benefit of both industries. The technology needs cited in this workshop related to the integration of the manufacturing life cycle and to the incorporation of concurrent, design engineering are the same technology needs that FASD is working to address in its work with the apparel industry. That work is described more fully in Appendix $\mathrm{C}$ of this report.

\subsection{Textile/Clothing Technology Corporation ([TC $\left.]^{2}\right)$}

Judson Early Director of $\mathrm{R} \& \mathrm{D}$

Textile/Clothing Technology Corporation Cary, NC

The Textile/Clothing Technology Corporation $[\mathrm{TC}]^{2}$ is a consortium that represents the apparel and textile industry (primarily apparel) and has over 200 members. The members can be broken down into the following categories (with the approximate number of members for each category in parentheses):

- manufacturers (105),

- associate members-suppliers (83),

- universities (44), and

- associations (33).

In addition, $[\mathrm{TC}]^{2}$ has ties with 14 international research organizations.

The mission of $[\mathrm{TC}]^{2}$ is to revitalize the U.S. soft goods industry through technology.

Technologies that $[\mathrm{TC}]^{2}$ has worked on that are relevant to custom shoe manufacturing include:

- body scanning,

- scanning standards,

- automated pattern adjustment, and

- ultra high-speed cutting - the ability to cut fabric up to $5 \mathrm{~m} / \mathrm{sec}(200 \mathrm{in} / \mathrm{sec})$.

$[\mathrm{TC}]^{2}$ stands ready to serve the footwear industry in whatever capacity it needs, including establishing a footwear demonstration center at its facility.

\subsection{The AMTEX Partnership ${ }^{\mathrm{TM}}$}

Richard Quisenberry

Executive Director, Program Industry Office

The AMTEX Partnership ${ }^{\mathrm{TM}}$

Wilmington, DE

Dr. Quisenberry was formerly Vice President of Research and Development at the

DuPont Corporation before accepting the directorship of AMTEX. 
The AMTEX Partnership ${ }^{\mathrm{TM}}$, initiated in mid-1992, is a research and development collaboration between the U.S. Department of Energy (DOE), the DOE's multiprogram laboratories, universities, and the integrated textile industry. The integrated industry includes fibers, textiles, apparel, and other fabricated products, as well as the retail sector. The goal of AMTEX is to strengthen the competitiveness of this vital U.S. industry and thereby preserve and create American jobs.

The AMTEX initiative features long range, strategic $\mathrm{R} \& \mathrm{D}$ planning, transfer of technology from the public to the private sectors, and an operational framework through which potential projects can be successfully implemented and directed. This cooperative alliance produces recommendations which are industry-driven, prioritized, and coordinated while employing the expertise and technology residing in the DOE-funded national laboratory system.

Currently, the U.S. productivity in the fiber and textile sectors, by any type of measure, is the top in the world. Those sectors are well capitalized and can better withstand the challenge of foreign competition than the apparel sector. Furthermore, if productivity is measured by the volume of product produced per worker, the U.S. is top in the world in apparel productivity as well. However, in terms of productivity per cost (where labor is expensive here), that isn't true. If you plot the market penetration (by percent) of foreign competition to the U.S. footwear market, it matches the apparel market penetration, if you offset the footwear market penetration eight years back (see Figure 1). ${ }^{19}$

The "apparel pipeline" (from fiber to finished apparel product on the retail shelf) is a total cycle of 66 weeks, on average. Of those 66 weeks, actual work in process is 11 weeks, and the rest55 weeks-is given to inventory, while the partially completed product is held until its next operation (see Figure 2).

One advantage that has led to the integrated textile industry's ability to organize quickly has been the independent laboratories already established to serve different segments of the industry. Those laboratories are referred to as Research, Education, and Technology Transfer Centers (or RETTs). The RETTS include:

- the Textile/Clothing Technology Corporation $\left([\mathrm{TC}]^{2}\right)$,

- the Textile Research Institute (TRI),

- the Institute of Textile Technology (ITT),

- Cotton, Inc., and

- the National Textile Center (NTC).

In the AMTEX arrangement, the RETTs own the technologies developed, including patents, and those technologies can be made available to any company in the U.S. AMTEX assigns a full time person to manage each AMTEX project.

Currently, six AMTEX projects are underway, and that number will be seven by next week (week of March 14, 1994), from sixty project proposals received in four different technology areas.

About one hundred industry companies and fifteen suppliers have currently signed up as AMTEX partners to participate with in-kind support to the projects, plus to contribute a yearly membership fee (with a floating scale based on the size of the company).

\footnotetext{
${ }^{19}$ Fawn Evenson made the comment that footwear has very low tariffs relative to apparel, with a resulting high import penetration (88\%). With the planned phase-out of tariffs for apparel products, foreign penetration to the American apparel market will accelerate.
} 


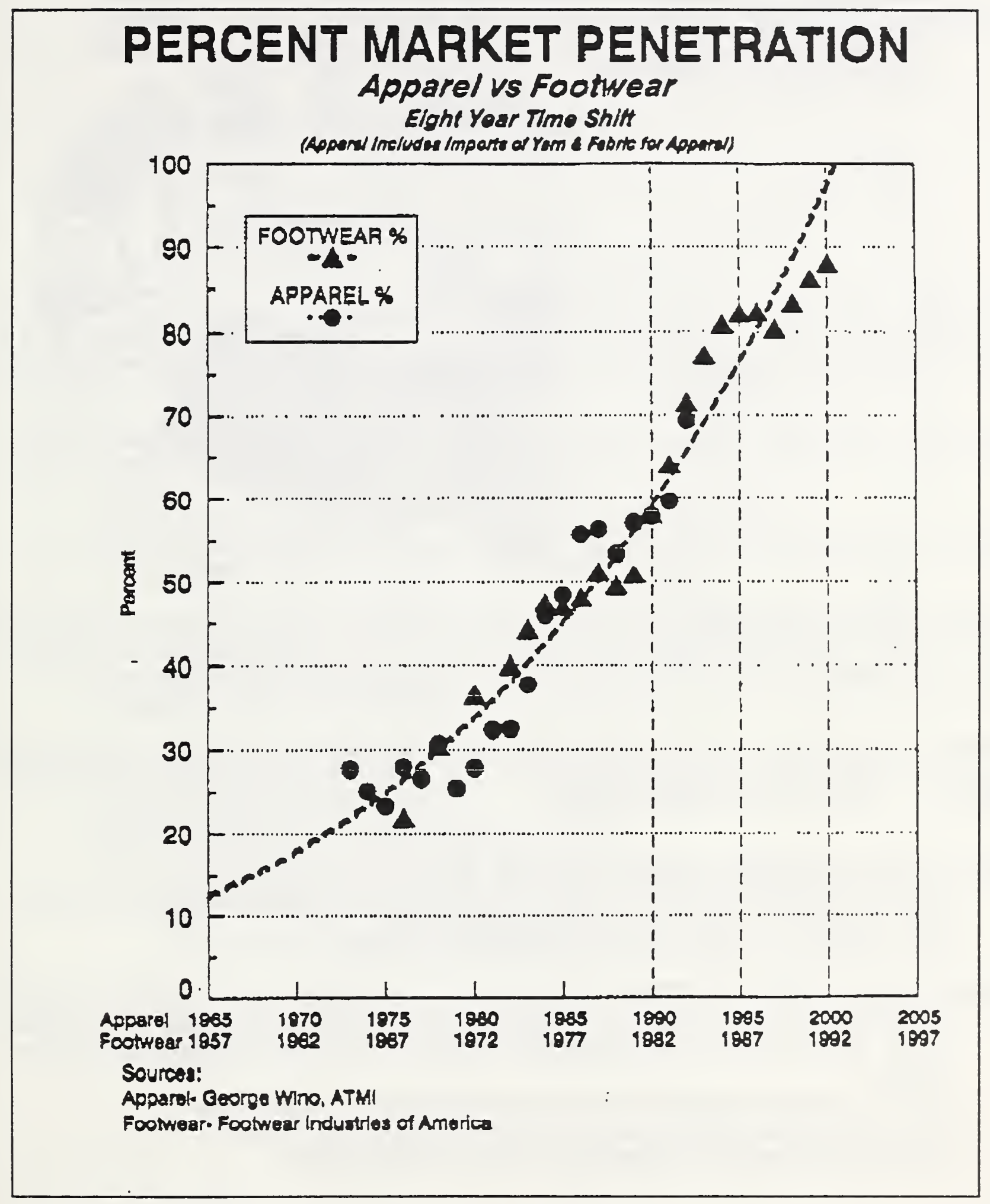

Figure 1 Apparel and Footwear Market Penetration 
66 - Week Apparel Pipeline

- Weeks in Process: $11(16.7 \%)$

- Weeks in inventory: 55 (83.3\%)

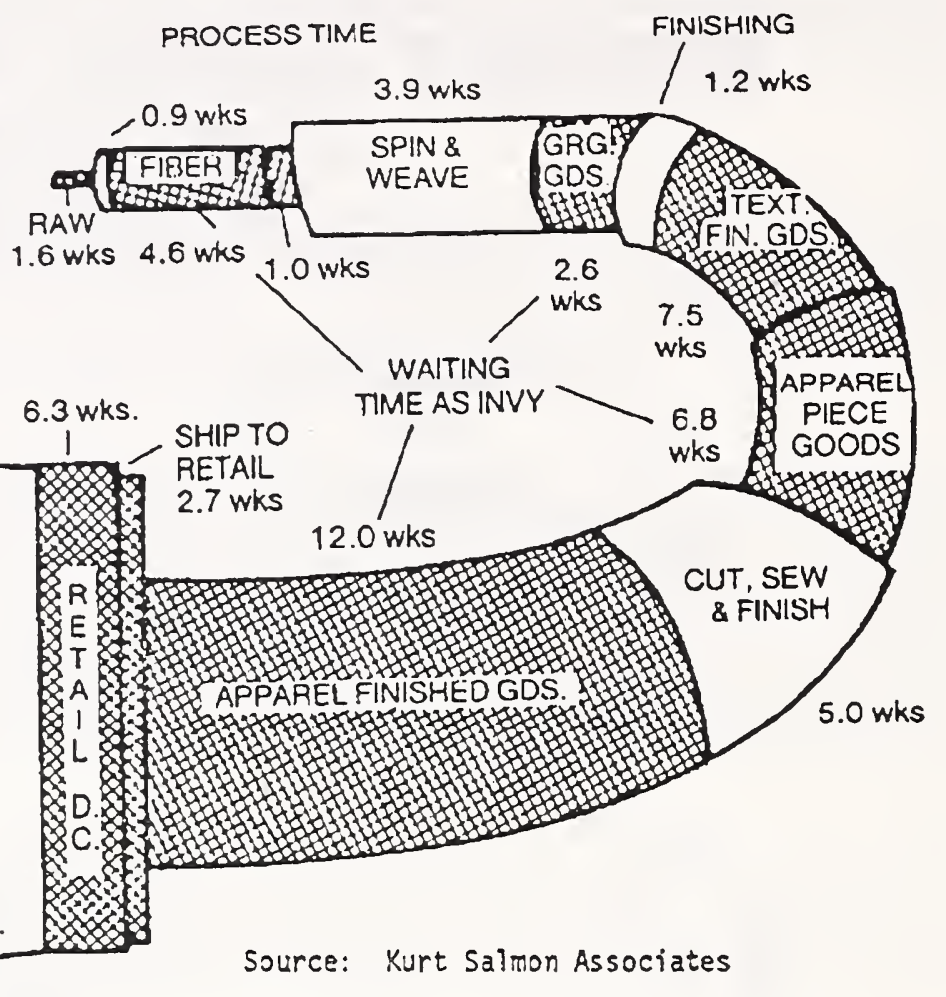

\section{Figure 2 The 66-Week Apparel Pipeline}

Within five years, the AMTEX program is projected to:

- ramp up to $\$ 100$ million a year in funding support (plus in-kind industry contributions),

- include 30 projects a year in 10 technical areas, and

- have 150 industry and 25 supplier companies as members.

The current objectives of the AMTEX program are to:

- reduce the pipeline from 66 to 33 weeks and recoup $\$ 12$ billion out of $\$ 25$ billion a year losses (this project is correspondingly obtaining half of the current AMTEX total budget),

- achieve a dramatic reduction in the cost of textile dyeing and finishing,

- advance the technology for computer-aided fabric inspection, ${ }^{20}$ and

- enable custom apparel manufacturing of one-of-a-kind products.

${ }^{20}$ Current technology now enables plain fabric to be automatically inspected for defects, but, so far, the technology cannot handle the inspection of fabrics with patterns or artistic designs. 
To create a new consortium, Dr. Quisenberry recommends:

- get the rules and procedures up front at the beginning,

- determine in advance the method for handling intellectual property rights, and

- establish a top operating board that includes the highest executive officer (with no delegation permitted) of each company that has a member on the board.

\title{
4.5 University of Massachusetts Dartmouth
}

\author{
Ron McNeil \\ Dean, School of Business and Industry \\ University of Massachusetts Dartmouth \\ No. Dartmouth, MA
}

From a business and marketing perspective, the therapeutic market for shoes is a natural niche. It is potentially a huge market when you consider the comparative government advantage of supporting the purchase of therapeutic footwear and avoiding the much larger medical cost that improper footwear can cause.

Of the footwear companies in Massachusetts, only a few have their manufacturing operations wholly or mostly in the U.S. Those companies include:

- Footjoy,

- George Keith Company (maker of Walkover golf shoes ${ }^{21}$ ), and

- New Balance (does $80 \%$ of its manufacturing in the U.S. and the rest in the Far East and Mexico).

The other footwear companies in Massachusetts are basically "trading" companies, in which all or most of the manufacturing is done in other countries. An example is:

- Rockport (which imports mainly from Yugoslavia and markets the shoes in the U.S. -distribution time is a problem).

To encourage Americans to buy American, the main issue that must be addressed is cost. Dr. McNeil recommends several strategies:

- improve manufacturing practices;

- look to technology for strategic advantages; and

- focus on less labor intensive processes to:

- possibly import shoe uppers,

- manufacturer bottoms here, and

- assemble the uppers and bottoms here.

Finally, Dr. McNeil recommends that a demonstration center is needed to take the custom footwear concept to a prototype demonstration system.

${ }^{21}$ There are 207 separate operations required to manufacture golf shoes. By distributing the shoes directly to golf pro shops, the company can charge more and make a higher profit on them. 
Bill Boettge

Executive Director

Pedorthic Footwear Association

Columbia, $\mathrm{MD}$

Bill Boettge is Executive Director of the Pedorthic Footwear Association and of the Board for Certification in Pedorthics. He also serves as President of the National Shoe Retailers Association. His background includes owner/operator of a retail shoe chain in the midwest. His experience of over thirty years in the footwear industry and as head of three footwear associations has resulted in his authoring many reports and presentations regarding footwear retailing and the pedorthic industry. He was honored in 1993 by Footwear News, the industry's trade publication, as Footwear Industry Person of the Year.

The average retail shoe store has the following characteristics:

- does about $\$ 400,000$ a year in gross revenue,

- has an inventory of about $\$ 100,000$,

- turns its inventory over about twice a year.

The inventory cost is further exacerbated by the not uncommon problem of customers walking out the door with mismatched shoes (i.e. a different sized left and right shoe) by mistake.

If technology could be applied to reduce the inventory required for retail stores, it would greatly reduce costs for those stores.

It has been estimated that between 4 to $7 \%$ of the U.S. population cannot be fit with "normal" off-the-shelf footwear. That estimate amounts to between 10 to 18 million people. As the median age of our population increases, the number of people needing special footwear will also increase. Figure 3 shows how the needs of those people are presently served.

The medical professional who sees most of the foot problems is the podiatrist. Often the podiatrist provides the specialized footwear needs of the patient directly (usually with removable orthoses), rather than referring those patients to a pedorthist. A pedorthist does not diagnose foot problems, instead working from a prescription from the medical professional. Figure 4 shows how a consumer goes through the system to remedy foot problems. (The dashed line indicates communication between the pedorthist and the medical community to meet the consumer's footwear needs.)

Ready-to-wear footwear having special characteristics, such as removable orthoses provided by a certified pedorthist or perhaps other modifications to the footwear, can service approximately 70 to $80 \%$ of the footwear needs of diabetic patients having foot problems. There is a growing trend, especially among orthopaedic doctors, to treat more feet with conservative management (i.e. proper footwear, including modifications to the footwear) rather than perform foot surgery. 
10 to 18 million Americans cannot be fit with normal off-the-shelf footwear. Below is an estimate of how their footwear needs are supplied today.

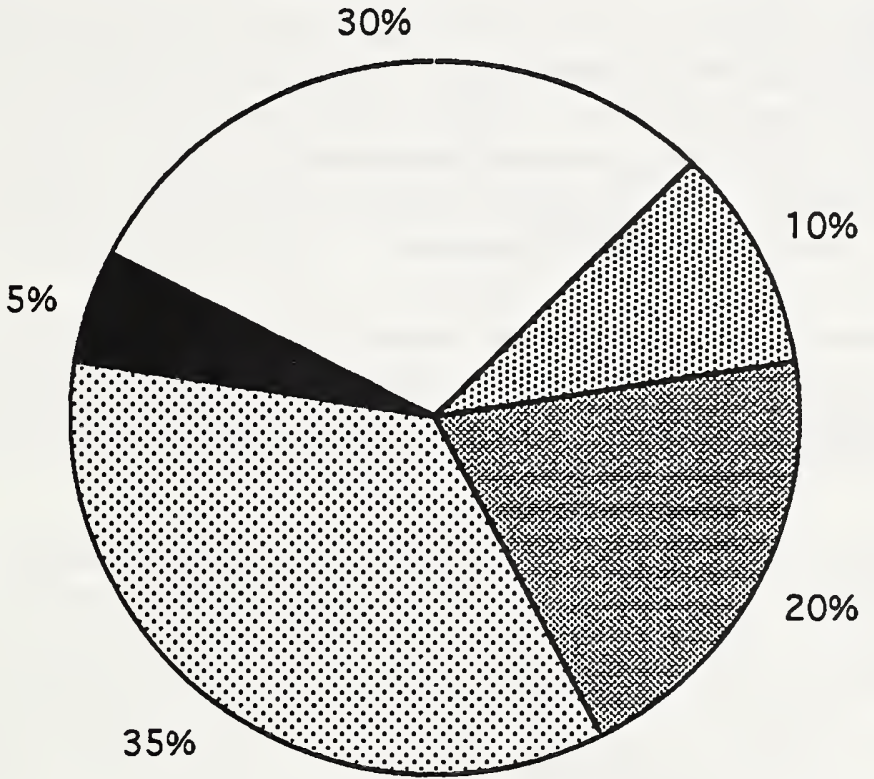

\section{鬹 Special \\ "unusual" size \\ Off-the-shelf with custom orthosis \\ Modified off- the-shelf \\ Custom-made \\ Needs unmet}

\section{Figure 3 Percent Americans that could Benefit from Various Types of Footwear}

Notes:

- Special "unusual" size-not custom made or customized. Either special ordered from manufacturer or found in a special size shoe store.

- Off-the-shelf with custom orthosis-footwear is not modified, but has a removable orthosis that is customized.

- Modified off-the-shelf-off-the-shelf therapeutic footwear and in some cases normal off-the-shelf footwear that is modified (wedged, offset heels, metatarsal bars, rigid rocker/roller bottom, extended counters, etc.), sometimes with a customized or custom orthosis also added.

- Custom-made-for therapeutic purposes. A custom therapeutic shoe is made for a specific person from a positive model of the patient's foot.

- Needs unmet-thus are homebound or in nursing home or using inappropriate footwear. 


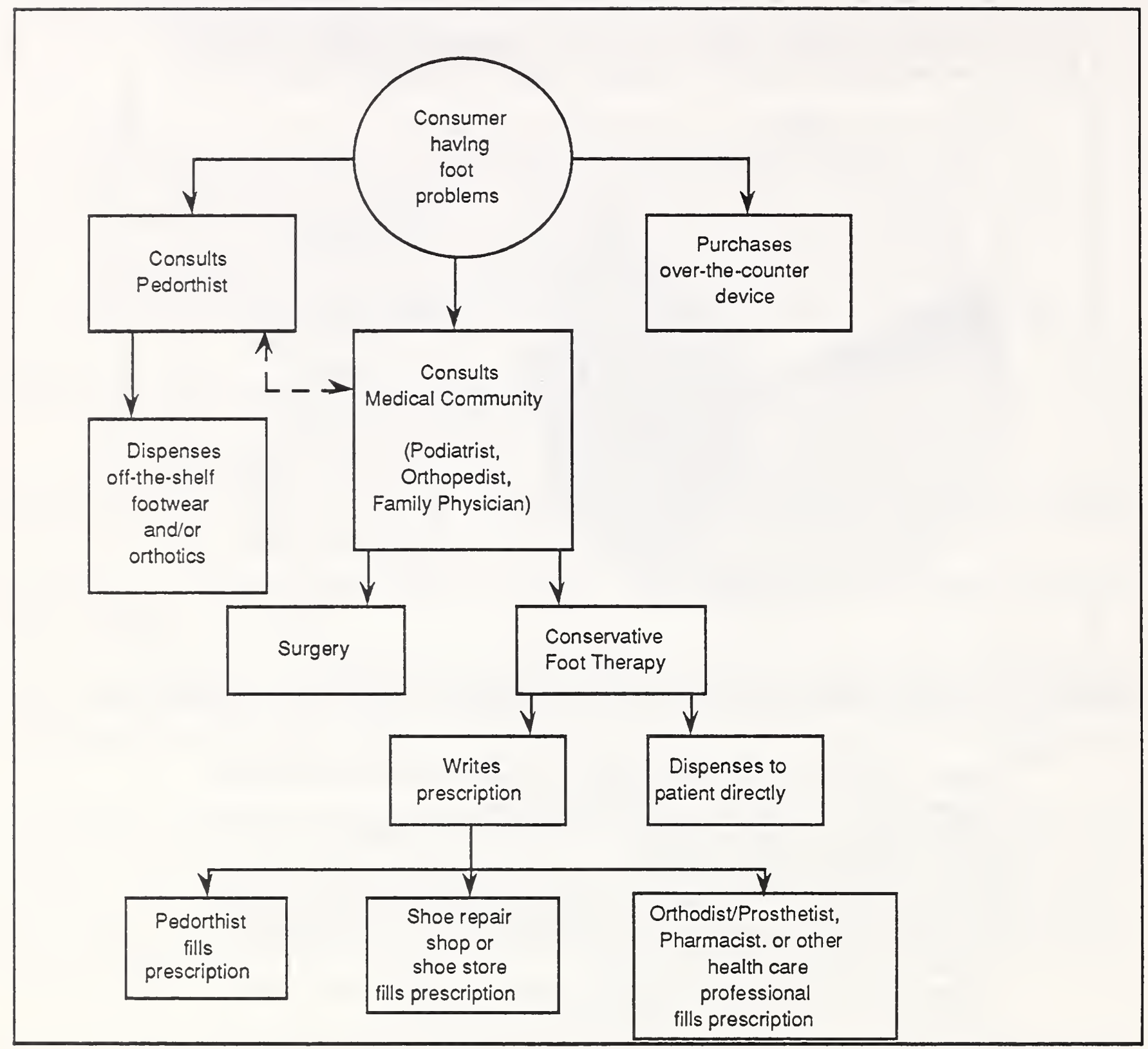

Figure 4 How a Consumer Has Foot Problems Resolved 


\title{
4.7 Footwear Industries of America (FIA)
}

\author{
Fawn Evenson \\ President \\ Footwear Industries of America \\ Washington, DC
}

Since 1974, Fawn Evenson has been a leader in the U.S. footwear industry's fight to remain competitive in the face of increasing, foreign competition. She has served Footwear Industries of America and its predecessor organization in a variety of positions, all with a continued focus on achieving federal government support through congressional legislation of the International Trade Commission. She was appointed President of Footwear Industries of America in August, 1987.

Before working for the footwear industry, Ms. Evenson was director of Congressional Relations at the Cost of Living Council, where she counseled Members of Congress and their staffs on stabilization policies and advised the Council of congressional interests, inquiries and activities.

The Footwear Industries of America (FIA) has 150 members, including most of the large shoe manufacturers and suppliers to the industry. FIA is 125 years old and has a staff of 9 in its DC office. The mission of FIA is to make the American footwear industry more competitive in the global market and serve as an information resource for the industry. Due to a lot of factories east of the Mississippi, it is no surprise that FIA has good contacts on the Hill. FIA lobbies for the industry, locates funding sources, and negotiates (e.g., the recent NAFTA agreement) as a representative of the industry.

In addition, FIA conducts conferences, workshops, and other events. It runs SHOE TECH every three years in Boston. (The next one is December $8-10,1995$.) SHOE TECH is a major trade show for the industry and features equipment, components, and systems. At the last SHOE $\mathrm{TECH}$, the main theme was computer technology relevant to footwear manufacturing-from design through production. FIA also has a very active schedule of export events, sponsoring USA Pavilions in eight trade shows overseas this year, for both finished product manufacturers and suppliers.

FIA can be a catalyst for the footwear industry. It can play a very active role to assemble the industry leaders to address important needs or problems of the industry.

\subsection{Shoe and Allied Trades Research Association (SATRA)}

Since the Shoe and Allied Trades Research Association (SATRA) did not have a representative at this workshop, Fawn Evenson presented a brief overview of SATRA, and subsequent to the meeting, Lee McKinley provided a draft overview. The following was taken from those two sources.

SATRA is an international footwear R \& D consortium that is supported by dues of its members, plus additional support from England and the European Union (EU). SATRA Footwear Technology Centre, Kettering, England, is a full partner of FIA. All FIA members are also members of SATRA and are extended all of the privileges of that membership, including access to the technology that is developed through SATRA's Research center. SATRA Footwear Technology Centre is the largest footwear research and development organization in the world. Based in Kettering, UK, it employs 170 scientists, technologists, and support staff. Since its inception in 1919, SATRA has grown from a mainly UK organization to an international concern 
with 1100 members in 50 countries. SATRA's longest standing service to members is evaluating materials and solving technical problems. Forty percent of SATRA's 4.5 million pounds annual budget is still invested in material and product research.

Over the past several years SATRA has embarked on the development of low cost, high technology, computer-based shop floor control systems aimed at reducing production costs. SATRA's computer-based materials assessment system, SATRASUMM, is used by over 125 footwear companies throughout the world. SATRA has done extensive work in 2-D and 3-D computer pattern grading. New systems in the works include the use of finite element analysis on outsoles, lasts, and other shoe components, as well as a computer system for manufacturing simulation a powerful management tool for pinpointing production bottlenecks.

In addition, SATRA has organized an international group of footwear technicians, researchers, and engineers from all of the major footwear and supplier countries throughout the world to develop standards that link computers to shoe production machines on the shop floor. This initiative, known as Intercim, makes SATRA the only footwear organization in the world attempting to integrate these protocols into the industry. Without these standards, true automation can never be realized in footwear manufacturing. 


\section{Panelists: Arnie Davis, Greg Alaimo, and Lee McKinley}

Arnie Davis: The therapeutic shoe is the most complex of footwear produced and generates the least revenue for the footwear industry.

Lee McKinley: In 1990 the Defense Logistics Agency (DLA) requested that FIA work with them on establishing a demonstration site for footwear, which would produce small test lots of combat boots and military dress shoes. The idea was to equip the site with advanced state-ofthe-art machinery, systems, and technology, and thereby demonstrate to the footwear industry how best to compete with foreign imports. The DLA was concerned that because of the closing of most domestic factories (today, at $88 \%$ import penetration), in the event of a national emergency, there would be no footwear manufacturing base to produce vital military footwear.

DLA claimed $\$ 6,000,000$ would be available for FIA over a period of five years, and that money would go towards equipping the site with the necessary machinery, personnel, and support. FIA spent over two years gathering support from the industry and its university partner, the University of Virginia (UVA). There was tremendous cooperation from everyone. The machinery suppliers committed to several million dollars worth of state-of-the-art equipment; UVA promised a building in Charlottesville; SATRA promised its support; industry executives all gave support to the effort and attended many DOD coalition meetings in preparation for the "instrumented shoe factory." Unfortunately, due to Congressional budget cutbacks, DLA abruptly canceled the project, and the proposed funding was withdrawn.

At that time, there was great interest in the demonstration center. Presently, if properly approached, and with guaranteed funding support, a newly created center for custom footwear manufacturing could tie in with an industry-wide program that would benefit not only custom footwear but also the ready-to-wear footwear industry.

The American footwear industry is very open and very closely connected-the ingredients for excellent collaboration possibilities. The idea of creating a demonstration site for collaborative $\mathrm{R} \& \mathrm{D}$ and demonstrations is a good one, and we should make that part of our plans-possibly as the starting point for our program.

Jud Early: The demonstration site idea works for the apparel industry, as witnessed by the success of the Defense Logistics Agency (DLA) program. DLA established three demonstration sites with five years of funding. Unfortunately, DLA funding (or any other single, government source) cannot be counted on continuously for the long term. Industry support is necessary, in addition to government support, for a long term successful program.

Howard Moncarz: We should define our proposed program in separate components, and then look for funding from separate government sources-each source identified from the one (or more) source/s that make the most sense for that component. That way the program will be stronger, and will not collapse from the reduction, or even complete withdrawal, from any one of the sources. Also, I believe that funding solicitations can be more successful, since the source would be more selectively targeted according to its particular interests.

Arnie Davis: We need a "white paper" that clarifies the industry's needs and the cost savings to the industry, as well as the country's health-care, cost savings, that could result from this program. We need real statistics from reliable sources.

Also, we need an organization to filter the information collected and generated in this program to the industry. 
One of the first things we need to do is identify the equipment we will need to start (at the demonstration center).

Robert Wallace: A reference model for the system is needed to be clear about the separate components of it.

Kathleen Robinette: Metrics should be identified that can measure the performance of the program - is it successful in its proposed endeavors (and by how much)?

Howard Moncarz: Developing an enterprise framework and data interface specifications can help address these issues. The specifications can be used to define the system components, and can serve as the vision that we want to work towards. They also can serve as a road map for our program to specify what work has been done, what is needed, and what are the priorities. Metrics can be defined and mapped to the program, once we put down in writing what that system (and program) will be. (DLA is using this approach to manage their apparel $R$ \& D program.)

Doug Ferguson: This program needs identity, support, sponsorship-an organizational approach. A business plan should be created that can focus the efforts and accomplish the goals.

William Davis: It is possible that the Orthopaedic Foot and Ankle Society would endorse the program for custom footwear because of its health benefits. That type of endorsement is analogous to the endorsement that the national dental organization gives to fluoride.

Jud Early: Analogous to the goal of custom footwear is the goal of apparel on demand. The apparel industry is working towards a five day turnaround time. Cost must be analyzed. For apparel, $10 \%$ of the ultimate retail cost is labor-meaning, reducing labor cost will not help that much. The other $90 \%$ of costs must be addressed. Those costs are largely due to time delays between operations, and for some operations themselves. Time should be used as a competitive weapon. Custom fit should be used to enable entry into markets beyond the U.S.

Fawn Evenson: For shoes, as much as $40 \%$ of the wholesale cost is labor, so reducing the labor costs for shoes is significant.

Robert Wallace: Manufacturing must be able to address a lot size of one.

Lee McKinley: That can be done and is being done today in many factories.

Fawn Evenson: A skilled pedorthist is needed to do the fitting. However, a service center is needed to process the demand and produce enough shoes. The system cannot be efficient enough to be successful if one person (for example the pedorthist) is doing everything.

Greg Alaimo \& Arnie Davis: Both also want to improve the quality of pedorthic shoes. It is possible, given enough time (and consequently money), to produce a therapeutic shoe that is attractive in a fair range of customer's style preferences. Technology that could reduce the time required for a footwear designer to do that would be very beneficial.

Arnie Davis: The cost of an attractive, pedorthic pair of shoes (the top of the line, including other accessories such as inserts, etc.) is about $\$ 1200$ (for men's shoes; women's shoes are more complex, and more expensive). Additionally, there is a charge to make the first last that can be reused for new shoes to that same customer (assuming not much therapeutic or style modifications are necessary). For a boot in certain fashions, the cost can be up to $\$ 2500$. 
Howard Moncarz: From what I am hearing, the industry need is for the technology to create an attractive, therapeutic shoe. Maybe the styles offered do not have to be the same as mainstream styles, to help accommodate the special shoe shapes needed for medical reasons.

Arnie Davis: My company is offering a new type of shoe at about $\$ 650$ a pair, that is produced with stock patterns that we have designed that can be modified for various therapeutic corrections and still be attractive.

William Davis: In Charlotte, VA, the shoe prices are probably cheaper than in San Francisco.

Arnie Davis: The advent of running and subsequent walking shoes with pull-out soles hurt the pedorthic footwear industry. People with minor foot problems can buy those shoes and replace the soles with some other insert without seeing a pedorthist. With less volume of shoes sold, the cost of the shoes and subsequent price to the consumer have been forced up.

Arnie recommends the approach of starting with a commercial, casual type shoe that looks commercial, and then use technology to modify that shoe for fit and therapeutic adjustments. Start with one style to develop the approach, and then expand the approach to other styles.

To get the most attractive shoe, some therapeutic advantage must be compromised, and vice versa. There is a limit to how much therapeutic correction is possible for a particular style of shoe. The women's pump is the most difficult shoe to modify for therapeutic corrections. That style should be the last style to tackle in trying to advance custom, therapeutic shoe technology. There is a tradeoff of comfort and style that must be understood by the consumer.

Unfortunately, expectations are very high for perfect fit when people buy custom shoes. They don't expect to have to break them in as with other shoes.

Janis Gregory: The public needs to be educated.

Arnie Davis: Yes, tell women that it is normal for their custom shoes to be tight in the toes for a couple of weeks.

Ron McNeil: Custom footwear must be physiologically appropriate and psychologically pleasing. Different categories of shoes must be promoted differently. For example, women's custom dress shoes should be promoted as good-looking, but not as good-feeling.

Fawn Evenson: To reduce health care costs, therapeutic shoes must be attractive and affordable. 


\subsection{Where Do We Go From Here? (Facilitator: Fawn Evenson)}

Bill Boettge: The custom shoe market is now a very small market, about 100,000 pairs a year. For promotional purposes, we should focus on the number of people who would be served by this effort. At least 3,000,000 Americans could benefit from custom shoes and lead more productive lives, saving millions of dollars in future foot related medical costs. Unfortunately, many of those people don't realize they need custom shoes. Good custom-made shoes today sell for about $\$ 400$ to $\$ 600$ and modified off-the-shelf therapeutic, and in some cases modified "normal" shoes, sell for about \$150 to \$225.

Discussion to determine a mission statement-suggestions include:

- To make available attractive and affordable custom footwear for all who need them to reduce health care costs

- To deliver a nationwide system by the year $\mathrm{X}$ that will provide $\mathrm{Y}$ footwear at $\mathrm{Z} \%$ the current cost

- To advance technology in the U.S. footwear industry

- To make the U.S. footwear industry more competitive in the world marketplace by: - making it more responsive to customer needs and

- applying new technology to it.

By-products: reduced health care cost, improved consumer education, improved fit, improved quality

Industry needs:

- Set up demonstration site for available technology

- Available to all

- Central location

- Set up a pilot plant

- Identify potential customers

- Evaluate available technology

- Develop world class industry

- Produce cost savings

- Reduce inventory (work in process and finished)

- Improve quality

- Reduce labor cost

- Improve customer education

- Identify market potential

- Determine industry, consumer, and relevant health care statistics

Arnie Davis: A site is needed for the demonstration center that services real cases.

Howard Moncarz: I suggest that we start by developing a prototype system in a laboratory setting that has the best $R \& D$ resources; then in the next step, transfer that technology to the pilot plant that sees real cases. The laboratory can continue to test new capabilities and use the input from the pilot plant for additional modifications. A pilot plant may not have the flexibility to try new ideas while servicing real cases at the same time. The laboratory will develop the technology. The pilot plant will test it out from a practical and business aspect.

Arnie Davis: The pilot plant shouldn't be at a particular company because of the unfair advantage it would give that company, but participating companies in the program should work on developing it. Possibly the test system in the laboratory could be developed for the manufacturing processes up through the pattern definition. 


\subsection{Resources Available from the Workshop Participants}

Representatives from the footwear and apparel industry expressed support for the proposed effort. Their comments are summarized below.

Jud Early - Textile/Clothing Technology Corporation ([TC $\left.]^{2}\right)$ :

- Stands ready to serve the American footwear industry-possibly as a demonstration site.

Fawn Evenson-Footwear Industries of America (FIA):

- Government contacts, lobbying

- Statistical support

- Underpinning of industry needs and solutions

SATRA (not at meeting; Fawn suggested some resources they might provide):

- Advice and counsel (possibly they could get European funding to do part of the project)

- Creation of a last database, searchable by specific criteria (worth exploring)

- Direct participation. They might be very interested in the program and decide to put effort in. They should be part of advisory board.

comment-Jud Early: Before getting SATRA involved, you should first look at regulations of the potential funding organizations you will go to. It is possible they might not allow technology out of the U.S.

Bill Boettge-Pedorthic Footwear Association (PFA):

- Shoe and Sport Talk (SST) is a communications network that is already installed and in operation for the footwear industry. The software for SST was developed under contract by several industry associations at a cost of $\$ 500,000$. PFA has authority to donate the use of that software to the demonstration cell to hook up to SST as in-kind support to match other funding. SST already has "buy-in" from large companies such as Reebok and Nike.

- PFA can provide statistics on people who need pedorthic footwear.

- Finally, PFA can provide contacts to custom shoe makers, the Diabetic Association, the American Podiatric Medical Association (APMA), Allied Health People, and dispensers of health care.

\subsection{Identifying Funding Sources}

Below is a list of potential funding sources that were discussed:

- Defense Logistics Agency (DLA)-might be more interested in phase two of this project.

- Advanced Research Project Agency (ARPA)-might be interested in pedorthic technologies.

- Equipment suppliers-Perhaps they would donate equipment as in-kind, matching support.

- Medical community-might be best engaged through teaching hospitals.

- Shoe and Allied Trades Research Association (SATRA)

- Blue Cross/Blue Shield-insurers might be interested in this effort, even without specific numbers, because of the potentially huge reduction in health care costs. 
Currently, they pay for foot operations, including amputations. However, a potential factor in preventing interest from the insurance industry is potential abuse.

- Defense Orthopedic Footwear Center (DOFC) in Boston

- State funding

- American Association of Retired People (AARP)

- Veterans Administration-they need to reduce their costs. Also, disabled veterans are a potential large beneficiary of this program.

- Prison system-maybe prisoners could be taught shoe repair; possibly prison labor could do shoe manufacturing (they do gloves now); though political and other considerations might make this idea infeasible.

\subsection{Conclusions and Action Items}

Based on the feedback of the participants, the Workshop was considered successful as the first step to launch an R \& D program for the footwear industry. The main conclusions reached as a result of the workshop were:

- The initial effort should focus on an R \& D program for therapeutic footwear.

- Advancing the technology for the therapeutic footwear industry can have a tremendous impact on reducing health care costs.

- A physical demonstration center, similar to the DLA apparel manufacturing demonstration centers, is needed as a component of the research program.

To continue the effort,

- A draft of the proceedings should be developed and circulated to the participants to develop an organization consensus to go forward. (This paper will serve as that draft. It will be circulated to the workshop participants as well as to others who express interest in this effort.)

- A small, manageable executive committee should be organized to direct and market the effort after the decision is made to go forward.

- As one of the first tasks, a "White Paper," that presents the vision for the program, should be drafted, and it should include reliable data that validates the conclusions of the paper.

- A small team should review the paper and presentation, complete it, and develop a framework of the research program required so that potential funding organizations can be contacted. 


\section{A WORKSHOP ATTENDEES' MAILING LIST}

Mr. Greg Alaimo

Vice President

Acor Orthopaedic, Inc.

18530 S. Miles Parkway

Cleveland, $\mathrm{OH} 44128$

Tel: (216) 662-4500

Fax: (216) 662-4547

Mr. Bill Boettge

Executive Director

Pedorthic Footwear Association

9861 Broken Land Parkway, Suite 255

Columbia, MD 21046-1151

Tel: (410) 381-8282

Fax: (410) 381-1167

Dr. Costas Chassapis, Professor

Department of Mechanical

Engineering

Stevens Institute of Technology

Castle Point

Hoboken, NJ 07030

Tel: (201) $216-5564$

Fax: (201) 216-8315

Mr. Arnie Davis

President

Davis Shoe Therapeutics

3921 Judah Street

San Francisco, CA 94122

Tel: (415) $661-8708$

Fax: (415) 661-4507

Dr. William Hodges Davis

American Orthopaedic Foot \& Ankle

Society

Miller Orthopaedic Clinic, Inc.

Medical Center Plaza

1001 Blythe Boulevard Suite 200

Charlotte, NC 28203

Tel: (704) $373-0544$

Fax: (704) $347-5320$
Mr. Judson Early

Director of R \& D

Textile/Clothing Technology Corporation

211 Gregson Drive

Cary, NC 27511-7909

Tel: (919) $380-2156$

Fax: (919) 380-2183

Ms. Fawn Evenson

President

Footwear Industries of America

1420 K Street, NW

Suite 600

Washington, DC 20005

Tel: (202) 789-1420

Fax: (202) 789-4058

Mr. Doug Ferguson

Principle Associate

South Carolina Research Authority

5300 International Blvd.

North Charleston, SC 29418

Tel: (803) $760-3300$

Fax: (803) $760-3250$

Ms. Jeane Ford 22

Apparel Program Manager

National Institute of Standards and

Technology

Metrology Building, Room A127

Gaithersburg, MD 20899

Tel: (301) $975-3747$

Fax: (301) 869-0917

Dr. Lynn Gerber 22

Chief of Rehabilitation Medicine Dept.

National Institutes of Health

Building 10, 6S 235

9000 Rockville Pike

Bethesda, MD 20892-0010

Tel: (301) 496-4733

Fax: (301) 402-0663

${ }^{22} \mathrm{Ms}$. Jeane Ford and Dr. Lynn Gerber could not attend the Charleston Workshop but have been key participants in the effort. 
Ms. Janis Gregory

Director

Meetings \& Conventions

Government Affairs

Pedorthic Footwear Association

9861 Broken Land Parkway, Suite 255

Columbia, MD 21046-1151

Tel: (410) $381-7278$ or (800) 673-8447

Fax: $\quad$ (410) $381-1167$

Dr. Robert Henderson

Director

South Carolina Research Authority

5300 International Blvd.

North Charleston, SC 29418

Tel: (803) 799-4070

Fax: (803) 252-7642

Mr. Ron Martell

CEO

Microdynamics, Inc.

10461 Brockwood Road

Dallas, TX 75238-1695

Tel: (214) 3431170

Fax: (214) 503-8571

Mr. Lee C. McKinley

Footwear Industry Consultant

101 Bay Colony Court

Chapel Hill, NC 27514

Tel: $\quad$ (919) $932-9346$ or

Fax: (none)

Dr. Ron McNeil, Dean

University of Massachusetts Dartmouth

School of Business and Industry

No. Dartmouth, MA 02742

Tel: $\quad(508) 999-8432$

Fax: $\quad$ (508) $999-8776$
Mr. Howard T. Moncarz

Research Engineer

National Institute of Standards and Technology

Metrology Building, Room A127

Gaithersburg, MD 20899

Tel: (301) 975-3548

Fax: (301) 869-0917

Dr. Steve Paquette

Anthropology Coordinator

Attn: STRNC-YBA

Anthropology Branch

Behavioral Science Div.

U.S. Army Natick

RD\&E Center

Natick, MA 01760-5020

Tel: (508) 651-5430

Fax: (508) 651-5527

Dr. Richard K. Quisenberry

Executive Director

Program Industry Office

The AMTEX Partnership ${ }^{\mathrm{TM}}$

Post Office Box 4670

Wilmington, DE 19807

Tel: (302) 999-6733

Fax: (302) 999-6736

Ms. Kathleen Robinette

Research Physical Anthropologist

AL/CFHD

Building 248

2255 H. St.

Wright Patterson Air Force Base

$\mathrm{OH} 45433-7022$

Tel: (513) 255-8810

Fax: (513) 255-9198

Mr. Robert J. Wallace

President

Electronic Softgood Products

P.O. Box 5035

Raleigh, NC 27650-5035

Tel: (919) 832-0106

Fax: same 


\section{B ENDORSEMENTS}

\section{B.1 Therapeutic Footwear Manufacturer}

Greg Alaimo

Vice President

Acor Orthopaedic, Inc. $\quad$ (Custom Footwear $•$ Orthodics $・$ Prosthetics $・$ Medical Equipment)

Custom shoe manufacturers have always relied on the shoe manufacturing industry for any spinoff technology that could apply to us. During our meeting we discussed the advent of unit bottoms, computer patterns, last grading and computer sizing, and how these processes relate to cost savings in manufacturing. Unfortunately, due to the labor intensive nature of the custom footwear industry, these recent upgrades in manufacturing do not apply to us. In our industry every order consists of two prototypes: a left and a right shoe.

I have attended Shoe-Tech in Boston and have watched with great interest how computer technology is being applied to the footwear manufacturing industry. Our problem is that we are so small, none of the technology transforms very easily. We have never represented enough of a market for the software/hardware manufacturers to address in a way that is profitable for them.

We see our market growing with the aging population and the government's more aggressive position on health care. Unfortunately, at the same time, we see our Canadian-counterpart companies far ahead of us in this field. The main reason is because of the active involvement by the Canadian Government, which is funding research. They have placed CAD/CAM technology in at least four small manufacturing companies in Canada within the last three years. Our competition has a three year head start on us!

I watched with particular interest the passing of NAFTA. I am not sure exactly what this will mean for my company. Will our new Canadian competitors be in a position to drive us out of business because of our lack of competitiveness in a market that currently uses this advanced technology?

We feel that this CAD/CAM technology is the largest advancement available to our industry since its inception.

We are aware that this technology is available, as discussed by Ron Martell. I have had conversations with all of the companies Ron refers to. As a small business our pockets are not deep enough to advance this technology on our own. All of the agreements made with these companies would be open ended. To me this means that for a fee they will develop an additional part of the system that was not included in the original, standard option. They will proceed and develop only with more funds from us.

I was involved with this concept about fifteen years ago when we purchased our first mini computer. This computer was for a more mainstream application: a business package. The proposed cost was $\$ 25,000.00$. The final cost after two years of grief was about $\$ 170,000$. I can only imagine what it will take to implement CAD/CAM on my own.

I feel that this team effort and an involvement by the Federal Government is the only viable way for us to obtain this technology. I fear that if this program does not move forward it just might signal the demise of our business. 


\section{B.2 American Orthopaedic Foot \& Ankle Society}

William Hodges Davis, M.D.

Orthopaedic Surgeon

Representative of the American Orthopaedic Foot \& Ankle Society (AOFAS)

[Letter from Dr. Davis to Glenn Pfeffer. Dr. Pfeffer, M.D., is Chairman of the AOFAS Committee on Orthoses-Footwear]:

I just wanted to report on my trip to Charleston to represent the Foot and Ankle Society at the NIST/South Carolina Research Authority Study Group meeting on the footwear industry. It was a fascinating experience, and I think this is something that both the Orthotics and Footwear committee, and the Foot and Ankle Society will be interested in supporting.

The National Institute of Standards and Technology (NIST) has been described as the NIH of industry. Their interest is primarily keeping American business competitive in the world market, as well as keeping American technology ahead of the needs of the American people. The Clinton Administration has increased their funding to allow for these types of initiatives. The purpose of this study group was to evaluate the footwear industry in general, and the therapeutic footwear industry specifically, for evaluation of present technology to see if it was up to standards of the industry, as well as look at new technology, and secondly, to see if there was any way that using new technology we could bring the cost of custom/therapeutic footwear down and make it available to more of our patients. The South Carolina Research Authority is a nonprofit organization designed to work with business to help them best use modern technology in a profitable manner. The organizations co-sponsored the conference.

The conference was attended by multiple persons, both strictly researchers and a number of industry experts. The shoewear industry as well as the computer industry were both represented. In addition, there were a number of organizations represented that had a stake in the project of this sort, including the Pedorthic Footwear Association and the apparel industry's technology arm.

I was present to present the health realities. I made a formal presentation concerning the problems with diabetics, with arthritic conditions, and with post traumatic conditions, as well as problems with forefoot deformities, including but not limited to bunions, hammer toes, and corns. I also reiterated some recent research done about the effects of footwear on creating problems that require interventional care. ${ }^{23}$

The group, once the problem was delineated, looked at the present technology as far as shoewear goes and how this technology can be extrapolated to the therapeutic industry. These are interesting concepts, both looking at the dollars involved, as well as the market. By the end of the conference, it began to take on the look of a small business, looking for start-up dollars to continue the process as well as attempting to determine where those dollars would be. The mission statement for the initiative that was begun at this conference was to make attractive and affordable custom shoewear available to Americans. It was the feeling of the group present that this could be done with some government aid and possibly some industry aid. It was thought that the best method to achieve this would be to develop a demonstration center to evaluate new technologies and coordinate the industry in education as well as research.

It is my belief that it is this type of initiative that the American Orthopaedic Foot and Ankle Society should be intimately involved in. The opportunity for true public education and

${ }^{23}$ His presentation is summarized in Section 3.2 of this report. 
preventative medicine are astounding. In addition, to take the forefront as the medical advisor to an initiative of this sort would only serve to enhance our goals. It is my feeling after attending this conference that in order for the group assembled to not appear self serving, there is a need for an affiliation with a physician group. I think the AOFAS is best suited for this role. I would be glad to stay involved in this initiative, and would be willing to report back to your committee, as well as to the Board of the AOFAS.

Again, thanks for allowing me to attend this conference. I will look forward to discussing this initiative with you at future meetings.

\section{B.3 Pedorthic Footwear Association}

\section{Bill Boettge}

Executive Director

I really enjoyed the meeting in Charleston last month. It was extremely helpful to me and the Pedorthic Footwear Association. We are also very excited about going forward with the research that was discussed at the meeting.

Two of PFA's four major objectives tie into our active participation in a project that involves the advancement of the custom shoe manufacturing technology. The two are:

- To act as a unified voice for the prescription and comfort footwear retailers, manufacturers, and suppliers in the multi-faceted foot health care industry

- To create a forum for the exchange of ideas, knowledge, and technical information among certified pedorthists, medical doctors, allied health specialists, manufacturers, and suppliers regarding the specialized needs of custom, prescription, and comfort footwear.

We are presently pulling together facts and figures regarding health statistics as they relate to the footwear industry, including the custom shoe portion.

\section{B.4 American Podiatric Medical Association}

Frank J. Malouff, MSHA

Executive Director

Congratulations on a successful meeting last weekend in Charleston, South Carolina. Bill Boettge of the Pedorthic Footwear Association has been kind enough to brief me on the success of the meeting. I repeat my previous regret that we could not attend the meeting due to a major meeting of our own at the same time.

Nonetheless, we are still interested in participating in your work group. It would be very much appreciated if you would send me any materials generated during the meeting or as a result of the meeting. We would also like to continue to be notified of future activities. It is my hope that we would be afforded another opportunity to participate. Thank you very much for your kindness. Congratulations on a successful workshop. 


\section{B.5 National Institutes of Health}

Lynn H. Gerber, M.D.

Chief, Rehabilitation Medicine Department

The Warren Grant Magnusen Clinical Center of the National Institutes of Health (NIH) supports the combined efforts of NIST and the SCRA in developing a collaborative R\&D effort in custom footwear manufacturing.

The NIH is a biomedical research facility. The Clinical Center (CC) of the NIH supports research of the NIH categorical institutes that involves research on human subjects. It is in this capacity that the $\mathrm{CC}$ wishes to collaborate.

The Rehabilitation Medicine Department of the CC, NIH has had a long standing interest in the foot. Clinical studies have centered around patients with insensitivity, pain and arthritis of the feet. The needs of these patients are three fold: a) properly evaluate the skin, and neuromuscular function and the kinetics and kinematics of the foot; b) design treatments to relieve pain and improve function and physical performance, through surgical and non-surgical means; and c) to evaluate treatment outcome.

The Rehabilitation Medicine Department is interested in identifying and classifying clinically relevant foot problems. Further, it is committed to describing how the foot functions and when there are mechanical, neurological, or soft tissue problems. Unusual uses for the foot such as sports or work related requirements need more specific information gathered.

Treatment of foot abnormalities, improving gait and performance in work and play and possibly preventing future problems is the strategy of good foot management. Treatment needs to be evaluated for efficacy and it needs to be further assessed with respect to risks and benefits, as well as costs.

The Rehabilitation Medicine Department is committed to evaluating footwear and learning about its efficacy, benefit to function and preservation of mechanical alignment. 


\section{C.1 Background}

Information is money. The more information that a manufacturing company has about its products and how to manufacture them, the quicker and cheaper the company can produce those products. However, to be useful, the information must be meaningful, accessible, usable, and sharable. It is the business of "information technology" to make that information useful.

The integrated textile industry 24 can benefit from information technology in two major ways [Moncarz1]. ${ }^{25}$ First of all, the information requirements of all sectors of the industry must be defined and standardized to enable effective integration of the entire multi-enterprise industry. Second, the apparel sector, in particular, must be strengthened by using information technology to improve apparel design engineering.

To provide effective integration of the industry, the information used to describe a product and how it should be manufactured must be defined and structured appropriately. The Standard for the Exchange of Product Model Data (STEP) is key-it enables information to be structured in a form that is useful.

STEP is an emerging international standard for representing product data throughout a product's design, manufacturing, distribution, and disposal life cycle. Many of the information requirements as well as the software tools being developed to support STEP are applicable for any manufacturing industry. To serve the needs for a particular industry, Application Protocols (APs) are developed that designate the specific information and application requirements for that industry.

\section{C.2 The APDES Project-Building Information Models for Apparel Product Data}

At the National Institute of Standards and Technology (NIST), we have been working on a project to develop a suite of APs for the apparel industry. The project is sponsored by the Defense Logistics Agency (DLA), and the work is being carried out in cooperation with the Apparel Research Committee (ARC) of the American Apparel Manufacturers Association (AAMA). The project has been named the Apparel Product Data Exchange Standard (APDES) project.

The APDES project is part of a substantial program sponsored by DLA to improve apparel manufacturing technology. In addition to NIST, participants in the DLA program include universities, as well as apparel companies and their suppliers. The DLA program is advancing technology from traditional size-based methods (ready-to-wear) to methods that use body measurements data directly (made-to-measure). Additionally, the program is advancing production methods from fixed procedures based on standard products to flexible, computerintegrated manufacturing using the standards developed in the APDES project. The new technologies developed are expected to lead to better fit, higher product quality, more economical unit-production methods, and quicker response. All told, the program is a broad evolution toward integrated enterprises, in which all phases of a product's life cycle are

\footnotetext{
${ }^{24}$ The term "integrated textile industry" refers to the entire multi-sector, vertical industry that includes the fiber, textile, fabricated product (including apparel ), and retail sectors. Note that the apparel sector is also referred to as the apparel industry in this brief.

${ }^{25}$ References are listed at the end of this section.
} 
coordinated through a framework of standards, concurrent engineering practice, and supporting technology.

The first objective of the APDES project was to demonstrate the feasibility of using STEP for apparel. We accomplished the objective in two parts. First, we developed an information model for pattern data using STEP technology [Lee1]. Second, we implemented the model in a computer program that exchanges pattern data between two industry formats, using the "STEP data structures" as an intermediary [Moncarz2].

Next, based on the Apparel Manufacturing Architecture (AMA) developed by the Georgia Institute of Technology [Jayaraman], we identified a set of APs that will enable integration of an entire apparel manufacturing enterprise [Moncarz3]. After identifying the APs that are required, we began specifying what those APs should be. We have completed specifying the first AP for "Ready-to-Wear Pattern Making" [Lee2], and we are currently working on the second for "Made-to-Measure Pattern Making."

\section{C.3 The AMTEX Partnership ${ }^{\mathrm{TM}}$-A Model for Government/Industry Collaboration}

In addition to the apparel research program sponsored by DLA, another research program on behalf of the entire integrated textile industry has begun. This latter program was started as a joint venture between the Department of Energy (DOE) and the integrated textile industry. The program, named The AMTEX Partnership, was established as a comprehensive approach to employ government/industry collaboration to strengthen the integrated textile industry.

We have been participating in AMTEX meetings related to information technology. Because of our work in the apparel industry and our experience in relevant technologies (information technology as well as other relevant technologies that NIST has experience in), we have been asked by DOE to be on the Government Management Committee with them in working with AMTEX. Currently, DOE and NIST are working on a Memorandum of Understanding (MOU) to formalize a collaboration in support of AMTEX.

\section{C.4 Proposals-Efforts to Expand NIST's Assistance to the Integrated Textile Industry}

In anticipation of expanding our efforts on behalf of the integrated textile industry, we have been working on a number of proposals for work that will build our program. The first proposal, to develop the foundations for a new discipline in apparel design engineering, is an umbrella that can incorporate the work we want to accomplish using information technology. That program consists of three parts:

- Development of integration technologies (to integrate the entire apparel product life cycle, in particular, the design process)

- Study of the apparel design process (to enable the development of improved methods and improved design software tools)

- Development of advanced prototype tools (to take advantage of the first two program components, and conversely, to lend further insight to them)

To help develop the integration technologies component mentioned above we have written a proposal to develop an Advanced Apparel Manufacturing Cell. Also, during the course of our study of apparel sizing methods to develop a Prototype Made-to-Measure Pattern Making AP, we have been asked by the Institute of Standards Research (a subsidiary of the American Society 
of Testing and Materials) to collaborate with them in the development of apparel sizing standards.

\section{C.4 References}

[Jayaraman] Jayaraman, S., "Design and Development of an Architecture for Computer-Integrated Manufacturing in the Apparel Industry," Textile Research Journal, Vol. 60, No. 5, May, 1990.

[Lee1] Lee, Y. T., On Extending the Standard for the Exchange of Product Data to Represent Two-Dimensional Apparel Pattern Pieces, NISTIR 4358, National Institute of Standards and Technology, Gaithersburg, MD, June 1990. ${ }^{26}$

[Lee2] Lee, Y. T. and Moncarz, H. T., A Prototype Application Protocol for Ready-toWear Pattern Making, NISTIR 5115, National Institute of Standards and Technology, Gaithersburg, MD, January 1993.

[Moncarz1] Moncarz, H. T., Information Technology Vision for the U.S. Fiber/Textile/Apparel Industry, NISTIR 4986, National Institute of Standards and Technology, Gaithersburg, MD, November 1992.

[Moncarz2] Moncarz, H. T. and Lee, Y. T., Apparel STEP Translator, NISTIR 4612, National Institute of Standards and Technology, Gaithersburg, MD, June 1991.

[Moncarz3] Moncarz, H. T. and Lee, Y. T., Report on Scoping the Apparel Manufacturing Enterprise; NISTIR 5106, National Institute of Standards and Technology, Gaithersburg, MD, January 1993.27

${ }^{26}$ All reports from the National Institute of Standards and Technology are available from the National Technical Information Service, Springfield, VA 22161.

${ }^{27}$ This paper was also published in the International Journal of Clothing Science and Technology, Volume 5, Number 3/4, MCB University Press, England, 1993. 


\begin{tabular}{|c|c|c|}
\hline Acronvm & Term & Definition/Comment \\
\hline AMA & $\begin{array}{l}\text { Apparel Manufacturing } \\
\text { Architecture }\end{array}$ & $\begin{array}{l}\text { formal specification of the functions required in an } \\
\text { apparel manufacturing enterprise; developed by the } \\
\text { Georgia Institute of Technology }\end{array}$ \\
\hline AP & Application Protocol & $\begin{array}{l}\text { designates the specific information and functional } \\
\text { requirements for a particular application }\end{array}$ \\
\hline APDES & $\begin{array}{l}\text { Apparel Product Data } \\
\text { Exchange Standard }\end{array}$ & $\begin{array}{l}\text { product data standards based on STEP that will enable } \\
\text { integration of the apparel manufacturing life cycle }\end{array}$ \\
\hline ATEC & $\begin{array}{l}\text { Apparel Technology } \\
\text { Program }\end{array}$ & $\begin{array}{l}\text { proposed program (in the NIST Manufacturing } \\
\text { Engineering Laboratory) to focus NIST resources in } \\
\text { collaboration with nationwide efforts on behalf of the } \\
\text { FTA, including footwear, industry }\end{array}$ \\
\hline ATP & $\begin{array}{l}\text { Advanced Technology } \\
\text { Program }\end{array}$ & $\begin{array}{l}\text { NIST extramural program to support new technology } \\
\text { development that has technical risk, but has potential } \\
\text { for large national benefit if successful }\end{array}$ \\
\hline CALS & $\begin{array}{l}\text { Continuous Acquisition and } \\
\text { Life-Cycle Support }\end{array}$ & $\begin{array}{l}\text { originated from DOD-support services for a product } \\
\text { throughout the entire design, manufacture, } \\
\text { distribution, and disposal life cycle }\end{array}$ \\
\hline DAMA & $\begin{array}{l}\text { Demand Activated } \\
\text { Manufacturing Architecture }\end{array}$ & $\begin{array}{l}\text { AMTEX project to ultimately enable consumers to } \\
\text { "pull" products through the system, rather than the } \\
\text { current system where manufacturers "push" products } \\
\text { through at great inefficiency }\end{array}$ \\
\hline EDI & Electronic Data Interchange & $\begin{array}{l}\text { the computer-to-computer exchange of structured } \\
\text { business data, such as invoices and purchase orders }\end{array}$ \\
\hline FTA & $\begin{array}{l}\text { Fiber/Textile/Apparel } \\
\text { Industry }\end{array}$ & $\begin{array}{l}\text { acronym for entire soft-goods industry complex; } \\
\text { referred to as integrated textile industry by AMTEX }\end{array}$ \\
\hline MEP & $\begin{array}{l}\text { Manufacturing Extension } \\
\text { Program }\end{array}$ & $\begin{array}{l}\text { NIST outreach program for technology transfer to } \\
\text { small and medium-sized manufacturers }\end{array}$ \\
\hline RETT & $\begin{array}{l}\text { Research, Education, \& } \\
\text { Technology Transfer }\end{array}$ & $\begin{array}{l}\text { independent laboratories that operate for the benefit of } \\
\text { the FTA industry }\end{array}$ \\
\hline SST & Shoe and Sport Talk & communication link for footwear industry (from PFA) \\
\hline STEP & $\begin{array}{l}\text { Standard for the Exchange } \\
\text { of Product Model Data }\end{array}$ & $\begin{array}{l}\text { an emerging international standard for representing } \\
\text { the physical and functional characteristics of a product } \\
\text { throughout the product's life cycle }\end{array}$ \\
\hline
\end{tabular}




\section{E ORGANIZATIONS RELEVANT TO THE FOOTWEAR INDUSTRY}

\begin{tabular}{|c|c|c|}
\hline Acronvm & Qrganization & Mission and/or Relevance to Footwear Industry \\
\hline AAMA & $\begin{array}{l}\text { American Apparel } \\
\text { Manufacturers Association }\end{array}$ & $\begin{array}{l}\text { improve the competitiveness of American apparel } \\
\text { manufacturers through collaborative efforts-includes } \\
\text { research, education and training, and business } \\
\text { practices }\end{array}$ \\
\hline AMTEX & $\begin{array}{l}\text { American Textile } \\
\text { Consortium } 28\end{array}$ & advance the technology base of the FTA industry \\
\hline AOFAS & $\begin{array}{l}\text { American Orthopaedic Foot } \\
\text { and Ankle Society }\end{array}$ & $\begin{array}{l}\text { founded in } 1969 \text {, and composed of members (630) of } \\
\text { the American Academy of Orthopaedic Surgeons, } \\
\text { who are interested in research on and education in the } \\
\text { care of the foot and ankle; sponsors continuing } \\
\text { medical education courses }\end{array}$ \\
\hline APMA & $\begin{array}{l}\text { American Podiatric } \\
\text { Medicine Association }\end{array}$ & $\begin{array}{l}\text { professional society of podiatrists, founded in } 1912 \text {, } \\
\text { with } 9800 \text { members, a staff of } 53 \text {, and a budget of } \\
\$ 6.77 \mathrm{M}\end{array}$ \\
\hline ARA & $\begin{array}{l}\text { American Retirement } \\
\text { Association }\end{array}$ & $\begin{array}{l}\text { senior citizens may have particular interest in health } \\
\text { issues related to custom, therapeutic footwear }\end{array}$ \\
\hline ARC & $\begin{array}{l}\text { Apparel Research } \\
\text { Committee (of the AAMA) }\end{array}$ & $\begin{array}{l}\text { conduct, identify, support, influence and disseminate } \\
\text { worldwide research and emerging technologies and } \\
\text { philosophies that will enable the U.S. apparel industry } \\
\text { to become more competitive in a global market } \\
\text { environment }\end{array}$ \\
\hline ARPA & $\begin{array}{l}\text { Advanced Research Project } \\
\text { Agency }\end{array}$ & $\begin{array}{l}\text { separately organized agency within DOD; engages in } \\
\text { advanced basic and applied research and development } \\
\text { projects essential to DOD, and conducts prototype } \\
\text { projects that embody technology that may be } \\
\text { incorporated into joint (DOD \& civilian) programs, } \\
\text { programs in support of deployed U.S. forces, or } \\
\text { selected Military Department programs and, on } \\
\text { request, assists the Military Departments in their } \\
\text { research and development efforts }\end{array}$ \\
\hline ASTM & $\begin{array}{l}\text { American Society for } \\
\text { Testing and Materials }\end{array}$ & $\begin{array}{l}\text { establish standards for materials, products, systems, } \\
\text { and services; founded in } 1898 \text {, now with a staff of } \\
200 \text {, and over } 35,0000 \text { members composed of } \\
\text { engineers, scientists, managers, professionals, } \\
\text { academicians, consumers, and skilled technicians } \\
\text { holding memberships as individuals in or } \\
\text { representatives of business firms, government } \\
\text { agencies, educational institutions, and laboratories }\end{array}$ \\
\hline
\end{tabular}

${ }^{28}$ The formal collaboration between DOE and AMTEX is named The AMTEX Partnership TM. 


\begin{tabular}{|c|c|c|}
\hline DLA & Defense Logistics Agency & $\begin{array}{l}\text { provide (as a combat support agency) effective and } \\
\text { efficient worldwide logistic support to the Military } \\
\text { Departments and the Unified and Specified } \\
\text { Commands under conditions of peace or war, as well } \\
\text { as to other DOD components, Federal civilian } \\
\text { agencies, foreign governments, and international } \\
\text { organizations, as assigned }\end{array}$ \\
\hline DOC & Department of Commerce & $\begin{array}{l}\text { encourage, serve, and promote the nation's } \\
\text { international trade, economic growth, and } \\
\text { technological advancement }\end{array}$ \\
\hline DOD & Department of Defense & $\begin{array}{l}\text { provide the military forces needed to deter war and } \\
\text { protect the security of our country; footwear is a } \\
\text { critical military need-a stable footwear industry is } \\
\text { essential to national security }\end{array}$ \\
\hline DOE & Department of Energy & $\begin{array}{l}\text { actively supporting the integrated textile industry } \\
\text { through The AMTEX Partnership }\end{array}$ \\
\hline DOFC & $\begin{array}{l}\text { Defense Orthopaedic } \\
\text { Footwear Center in Boston }\end{array}$ & center specifically devoted to orthopaedic footwear \\
\hline FIA & $\begin{array}{l}\text { Footwear Industries of } \\
\text { America }\end{array}$ & $\begin{array}{l}\text { enable the American footwear industry to become } \\
\text { more competitive in the global market and serve as an } \\
\text { information resource for the industry }\end{array}$ \\
\hline ISR & $\begin{array}{l}\text { Institute of Standards } \\
\text { Research }\end{array}$ & $\begin{array}{l}\text { coordinate the development of consortia for creating } \\
\text { new standards (subsidiary of ASTM) }\end{array}$ \\
\hline ITAC & $\begin{array}{l}\text { Industrial Technology } \\
\text { Assistance Corporation }\end{array}$ & $\begin{array}{l}\text { transfer technology to New York State companies to } \\
\text { strengthen them }\end{array}$ \\
\hline NIST & $\begin{array}{l}\text { National Institute of } \\
\text { Standards and Technology }\end{array}$ & $\begin{array}{l}\text { improve the technology base of American industry } \\
\text { through the development and transfer of technology to } \\
\text { industry and through the development of standards }\end{array}$ \\
\hline $\mathrm{NIH}$ & National Institutes of Health & $\begin{array}{l}\text { the principal biomedical research agency of the } \\
\text { Federal Government, its mission is to pursue } \\
\text { knowledge to improve human health; seeks to expand } \\
\text { fundamental knowledge about the nature and behavior } \\
\text { of living systems, to apply that knowledge to extend } \\
\text { the health of human lives, and to reduce the burdens } \\
\text { resulting from disease and disability. }\end{array}$ \\
\hline NTC & National Textile Center & $\begin{array}{l}\text { fund collaborative university research for the entire } \\
\text { FTA industry }\end{array}$ \\
\hline
\end{tabular}




\begin{tabular}{|l|l|l|}
\hline PFA & $\begin{array}{l}\text { Pedorthic Footwear } \\
\text { Association }\end{array}$ & $\begin{array}{l}\text { represent both retail and manufacturing segments of } \\
\text { the pedorthic profession; members share interest in } \\
\text { pedorthic management of the foot from practice and } \\
\text { treatment to education and research }\end{array}$ \\
\hline SATRA & $\begin{array}{l}\text { Shoe and Allied Trades } \\
\text { Research Association }\end{array}$ & $\begin{array}{l}\text { advance the technology base of the footwear and } \\
\text { allied industries }\end{array}$ \\
\hline SCRA & $\begin{array}{l}\text { South Carolina Research } \\
\text { Authority }\end{array}$ & $\begin{array}{l}\text { advance the manufacturing-technology base for } \\
\text { American industry }\end{array}$ \\
\hline [TC] & $\begin{array}{l}\text { Textile/Clothing } \\
\text { Technology Corporation }\end{array}$ & $\begin{array}{l}\text { revitalize the U.S. soft goods industry through } \\
\text { technology; its operation includes demonstrations, } \\
\text { education, and research and development }\end{array}$ \\
\hline VA & $\begin{array}{l}\text { Veterans Administration } \\
\text { operate programs to benefit veterans and members of } \\
\text { their families; benefits include compensation } \\
\text { payments for disabilities or death related to military } \\
\text { service, pensions, education and rehabilitation, home } \\
\text { loan guaranty, burial, and a medical care program } \\
\text { (incorporating nursing homes, clinics, and medical } \\
\text { centers) }\end{array}$ \\
\hline
\end{tabular}




